OPEN ACCESS

Edited by:

Linda Nedbalová,

Faculty of Science, Charles University,

Czechia

Reviewed by:

Thomas Leya

Branch Bioanalytics

and Bioprocesses (IZI-BB),

Potsdam-Golm, Germany

Claire Remacle,

University of Liège, Belgium

*Correspondence:

Francisca E. Gálvez

franciscaelibethgalvez@gmail.com

Specialty section:

This article was submitted to Marine and Freshwater Plants,

a section of the journal

Frontiers in Plant Science

Received: 01 February 2021

Accepted: 10 May 2021

Published: 07 June 2021

Citation:

Gálvez FE,

Saldarriaga-Córdoba M, Huovinen $P$,

Silva AX and Gómez I (2021) Revealing the Characteristics of the Antarctic Snow Alga Chlorominima collina gen. et $s p$. nov. Through Taxonomy, Physiology, and Transcriptomics.

Front. Plant Sci. 12:662298. doi: 10.3389/fpls.2021.662298

\section{Revealing the Characteristics of the Antarctic Snow Alga Chlorominima collina gen. et sp. nov. Through Taxonomy, Physiology, and Transcriptomics}

\author{
Francisca E. Gálvez ${ }^{1,2 *}$, Mónica Saldarriaga-Córdoba ${ }^{3}$, Pirjo Huovinen ${ }^{1,2}$, \\ Andrea X. Silva ${ }^{4,5}$ and Iván Gómez ${ }^{1,2}$
}

${ }^{1}$ Instituto de Ciencias Marinas y Limnológicas, Facultad de Ciencias, Universidad Austral de Chile, Valdivia, Chile, ${ }^{2}$ Centro FONDAP de Investigación en Dinámica de Ecosistemas Marinos de Altas Latitudes (IDEAL), Valdivia, Chile, ${ }^{3}$ Centro de Investigación en Recursos Naturales y Sustentabilidad (CIRENYS), Universidad Bernardo O'Higgins, Santiago, Chile, ${ }^{4}$ Instituto de Ciencias Ambientales y Evolutivas, Facultad de Ciencias, Universidad Austral de Chile, Valdivia, Chile,

${ }^{5}$ AUSTRAL-omics, Vicerrectoría de Investigación, Desarrollo y Creación Artística, Universidad Austral de Chile, Valdivia, Chile

Snow algae play crucial roles in cold ecosystems, however, many aspects related to their biology, adaptations and especially their diversity are not well known. To improve the identification of snow algae from colored snow, in the present study we used a polyphasic approach to describe a new Antarctic genus, Chlorominima with the species type Chlorominima collina. This new taxon was isolated of colored snow collected from the Collins Glacier (King George Island) in the Maritime Antarctic region. Microscopy revealed biflagellated ellipsoidal cells with a rounded posterior end, a C-shaped parietal chloroplast without a pyrenoid, eyespot, and discrete papillae. Several of these characteristics are typical of the genus Chloromonas, but the new isolate differs from the described species of this genus by the unusual small size of the cells, the presence of several vacuoles, the position of the nucleus and the shape of the chloroplast. Molecular analyzes confirm that the isolated alga does not belong to Chloromonas and therefore forms an independent lineage, which is closely related to other unidentified Antarctic and Arctic strains, forming a polar subclade in the Stephanosphaerinia phylogroup within the Chlamydomonadales. Secondary structure comparisons of the ITS2 rDNA marker support the idea that new strain is a distinct taxon within of Caudivolvoxa. Physiological experiments revealed psychrophilic characteristics, which are typical of true snow algae. This status was confirmed by the partial transcriptome obtained at $2^{\circ} \mathrm{C}$, in which various cold-responsive and cryoprotective genes were identified. This study explores the systematics, cold acclimatization strategies and their implications for the Antarctic snow flora.

Keywords: Antarctic, Chlorominima, polyphasic approach, psychrophilic, snow algae, cysts, transcriptome 


\section{INTRODUCTION}

The cryospheric biome is dominated by highly specialized microorganisms that thrive under extreme low temperatures at the interface between snow/ice and liquid water (Anesio and Laybourn-Parry, 2012). The basis of these microbial communities, and hence the precursors of inorganic carbon fixation and primary source of macromolecules, are snow and ice algae, and cyanobacteria (Boetius et al., 2015; Anesio et al., 2017). Especially during the thaw season, these algae actively fix carbon (Yallop et al., 2012; Lutz et al., 2014). In fact, daily measurements of gas exchange in dense patches of snow algae have shown values of $\mathrm{CO}_{2}$ uptake close to $2,300 \mu \mathrm{mol} \mathrm{m} \mathrm{m}^{-2}$ day $^{-1}$, indicating that summer snowfields can be surprisingly productive and even in some circumstances can be a significant $\mathrm{CO}_{2}$ sink (Williams et al., 2003; Hamilton and Havig, 2017). Snow algae play crucial ecological roles as foundation organisms sustaining a high diversity of heterotrophic micro-eukaryotes, bacteria, and archaea (Lutz et al., 2015; Havig and Hamilton, 2019). The biological interactions within these communities, especially mutualism, have enhanced resilience to changes in the snow environment (Krug et al., 2020). In fact, it has been suggested that such biological processes can promote horizontal exchange and recombination of genetic material, which enables the acquisition of new genes, enhancing diversity (Lyon and Mock, 2014; Liu et al., 2018).

The identification of snow algae had previously been limited to morphological observations of cysts of red snow that were recognized as zygotes of the algae Chlamydomonas nivalis (Bauer) Wille and Chloromonas nivalis (Chodat) Hoham and Mullet. Therefore, these species were recurrently associated with the global distribution of cysts, resulting in cosmopolitan species (Marchant, 1982; Gradinger and Nürnberg, 1996; Müller et al., 1998). In the case of green snow, the identification of vegetative cells, also was normally based only on microscopic observations (Kol, 1968; Ettl, 1970). This has probably challenged the comprehensive identification of cryosestic algae in the past. However, the use of polyphasic approaches that include the combined use of multi-gene analyses, light and electron microscopy, biochemical and physiological approaches (Pröschold and Leliaert, 2007), strain designations by culture collections, as well as a better access to samples from previously inaccessible regions, has allowed both the reexamination of many strains of snow algae and the description of novel lineages (Muramoto et al., 2010; Demchenko et al., 2012; Matsuzaki et al., 2014; Hoham and Remias, 2020). To the date, polyphasic analyses show that field-collected cysts identified as Chloromonas nivalis zygotes consist actually of multiple species (Matsuzaki et al., 2018, 2019). Extensive phylogenetic analyses performed on the Chlamydomonas-Chloromonas complex have shown that 21 taxa from cold environments occur in four clades (Hoham et al., 2002; Remias et al., 2010) being most of the snow algae included in the phylogroup Chloromonadinia (Nakada et al., 2008). Another clade composed of algae that cause reddish coloration includes the new genus Sanguina (Procházková et al., 2019a). Thus, it is possible to argue that diversity of snow algae has been underestimated and is just being revealed.
For Antarctica, since the first microscopic surveys (Fogg, 1967; Kol, 1971; Broady, 1996; Ling, 1996) it has been recognized that snow fields from continental and insular regions host abundant and diverse communities of snow algae. However, only few of these snow algae have been identified with certainty (Ling, 1996). In the case of the Maritime Antarctic region, especially the South Shetland Islands, the snow algae communities were dominated by species of the Trebouxiophyceae and Chlorophyceae classes, whose structure and functional traits are set basically by the marine influence, sources of eutrophication and color of bloom (Komárek and Komárek, 1999, 2001; Soto et al., 2020).

Considering that regional warming has become an important environmental threat in the Maritime Antarctic (Vaughan et al., 2003), the biological processes, and fate of snow microbial communities will be strongly impacted by melting (Boetius et al., 2015; Garcia-Lopez and Cid, 2017). For example, the Collins Glacier in King George Island, has lost $8.42 \%$ of its mass between 1,983 and 2,012, mostly in the north and central-west sectors (Cook, 2005; Simoes et al., 2015). In a first stage, snow algae could be favored in ablation zones as melting provides suitable environments for their development, thus reducing albedo and exacerbating melting (Huovinen et al., 2018). As a contribution to the knowledge of the Antarctic cryoflora, we isolated a new alga (Chlorominima) from the red snow of this glacier that is in close proximity to the coast. Snowfields close to marine bird and seal colonies are typical sites for the development of snow algae in Antarctica due to a high nutrient input (Kol and Flint, 1968; Komárek and Komárek, 1999; Remias et al., 2013). To continue monitoring the consequences of melting of the glaciers on the microbial diversity it is relevant not only to perform accurate taxonomic identifications, but also to characterize physiological responses and perform gene profiling to gain insight into the dynamic and functions of snow algae under changing environmental scenarios (Cvetkovska et al., 2017; Garcia-Lopez and Cid, 2017).

The present study aimed (i) to propose a new genus, with the species type Chlorominima collina identified through an integrative approach of cultures obtained from samples collected from the Collins Glacier, King George Island; and (ii) to combine physiological and transcriptional approaches to describe some key adaptive traits that allow this organism thriving under permanently low temperatures. Thus, this report connects systematics aspects with the ecology and functionality of an Antarctic snow alga from a region that is being impacted by multiple environmental changes.

\section{MATERIALS AND METHODS}

\section{Sample Collection, Isolation and Cultivation}

Red snow samples were collected from the surface of the Collins Glacier, King George Island, South Shetland Islands $\left(62^{\circ} 10^{\prime} 5.412^{\prime \prime} \mathrm{S}, 58^{\circ} 51^{\prime} 18.216^{\prime \prime} \mathrm{W}\right)$, in February 2018. Each sample (approximately $400 \mathrm{~g}$ ) was excavated $5 \mathrm{~cm}$ deep with a sterile metal spatula, transferred to an $18 \mathrm{~cm} \times 20 \mathrm{~cm}$ sterile plastic bag and transported to the laboratory in the station "Base Profesor 
Julio Escudero." After melting at $4^{\circ} \mathrm{C}$, aliquots of $40 \mathrm{ml}$ were stored in culture bottles (TR6000, TrueLine, United States) with $10 \mathrm{ml}$ of $1 \%$ Bold's basal medium (BBM, Bischoff and Bold, 1963). These bottles were transported in a cooling box at no more than $10^{\circ} \mathrm{C}$ to the Photobiology Laboratory of the Universidad Austral de Chile, in Valdivia, where they were kept in a cold room at $1^{\circ} \mathrm{C}$. Samples were taken from one of the bottles in a 2.0-ml graduated microcentrifuge tube (Sorenson ${ }^{\mathrm{TM}}$ BioScience, Inc., United States) under a laminar flow hood. Cysts were harvested and washed by centrifugation $(3,500 \mathrm{rpm}$ for $5 \mathrm{~min}$ at $4^{\circ} \mathrm{C}$ ) four times with $1 \%$ BBM. Before cyst selection, the samples were examined under light microscopy to ensure that the cysts were free of other algae or microorganisms. Most of the observed cysts were in an early developing stage. Individual cysts were isolated manually under a microscope with a sterile glass micropipette (from Pasteur pipette) and then sown on agar plates with $1 \%$ BBM. The plates were kept in a cold room at $2{ }^{\circ} \mathrm{C}$ with a photoperiod of 16:8 h light:dark (L:D) at photosynthetically active radiation (PAR) of $20-30 \mu \mathrm{mol} \mathrm{m} \mathrm{m}^{-2} \mathrm{~s}^{-1}$ provided by fluorescent tubes (T8, 36W-cold white, Westinghouse). The first green colonies were obtained after 8 weeks (Figure 1). A strain was isolated by means of serial dilutions in combination with differential centrifugation (Andersen, 2005). The isolated strain was transferred to Erlenmeyer flasks containing 1\% BBM and cultivated in a cold room at $2^{\circ} \mathrm{C}$. The isolate has been deposited and is available in the Culture Collection of Algae and Protozoa (CCAP), SAMS Limited, Scottish Marine institute, under strain number CCAP 6/1.

\section{Light and Electron Microscopy}

The isolate was studied under light microscopy with an Olympus BX51 (Tokyo, Japan). Photomicrographs were taken with a QImaging MicroPublisher 5.0 digital camera, with Real Time Viewing (RTV). The QCapture Pro-6.0 (Teledyne Photometrics, Tucson, AR, United States) microimaging software was used to process images and obtain morphometric measurements of the cells. For transmission electron microscopy (TEM) two samples were taken, one of the mother culture with fresh medium and other from an old culture, both kept at $2^{\circ} \mathrm{C}$. These samples were fixed in $2.5 \%$ glutaraldehyde and $0.1 \mathrm{M}$ sodium cacodylate buffer $(\mathrm{pH} 7.2)$ for $24 \mathrm{~h}$. Samples were washed with the cacodylate buffer $(3 \times 15 \mathrm{~min})$ and subsequently fixed in $1 \% \mathrm{OsO}_{4}$ at $4^{\circ} \mathrm{C}$ under shaking. After washing with deionized water $(3 \times 15 \mathrm{~min})$ the fixed samples were dehydrated through a series of ethanol $(35,50,70,80,96$, and $100 \%$ for $10 \mathrm{~min}$ each), transferred to acetone $(3 \times 100 \%$ for $15 \mathrm{~min})$ and finally embedded in epon resin: acetone-epon (1:1) from the EMBed-812 kit and then left in neat epon for polymerization at $60{ }^{\circ} \mathrm{C}$ during $24 \mathrm{~h}$. Semi-fine sections (stained with toluidine blue) and ultra-fine sections were prepared with a Leica EM UC7 automatic ultramicrotome (Leica, Germany) and stained with $2 \%$ aqueous uranyl acetate and lead citrate for $5 \mathrm{~min}$. The sections were examined using a Libra 120 Plus Transmission Electron Microscope, 80,000 KV acceleration voltage (Carl Zeiss, Germany). Photomicrographs were obtained using a Veleta CCD camera (EMSIS) equipped with Zemas V2.0 image analysis software. The images were tagged with Adobe Illustrator 2019 (version 23.03).

\section{DNA Extraction, PCR and Sequencing}

Total genomic DNA was extracted with the GenElute Plant Genomic DNA Miniprep Kit (Sigma-Aldrich). According to this protocol, cells were ground in a mortar and pestle with liquid nitrogen, until obtaining $100 \mathrm{mg}$ of powder. PCRs were performed using KAPA Taq HotStart PCR Kit, in a total volume of $12.5 \mu \mathrm{l}(6.25 \mu \mathrm{l}$ of the mix, $2.5 \mu \mathrm{l}$ of primers and $1.25 \mu \mathrm{l}$ of DNA). The $18 \mathrm{~S}$ rRNA gene was amplified using the universal eukaryotic primers NS1 (White et al., 1990) and 18L (Hamby et al., 1988), with the cycling program as described in a previous study (Barcyte et al., 2018a). The region was sequenced with primers NS1 (White et al., 1990), 891F, 1122F (T. Friedl, unpublished) 18L (Hamby et al., 1988), 895R (Remias et al., 2012), and 1122R (T Friedl, unpublished). The complete region of the ITS was amplified with the ITS1 and ITS4 primers (White et al., 1990), following the cycling program of Barcyte et al. (2018a). The region was sequenced with primers ITS1 (White et al., 1990), 1800F (Friedl, 1996), 5.8 SbF (Mikhailyuk et al., 2008) and ITS2, ITS4, and LR3 (Vilgalys and Hester, 1990). Finally, a part of the ribulose-1,5-biphosphate carboxylase oxygenase (Rubisco) large subunit ( $\mathrm{rbcL}$ ) gene was amplified and sequenced with the primers rbcL1F and rbcL23R and the cycling program detailed in a previous study (Hoham et al., 2002). The PCR products were purified using the E.Z.N.A gel extraction Kit (Omega Bio-tek) and sequenced at Austral-Omics core facility at Universidad Austral de Chile. New sequences are available in GenBank under accession numbers MW554521 and MW553075.

\section{Phylogenetic Analysis}

The BLAST algorithm (Altschul et al., 1990) from Geneious Prime $(2019.2 .1)^{1}$, was used to search for sequence identifiers of the 18S rRNA genes, rbcL and ITS of species closely related to the isolated strain, in addition to other representatives of the order Chlamydomonadales used in previous studies (Hoham et al., 2002; Barcyte et al., 2018a). Sequence assembly, alignment and verification to detect possible misaligned positions were made in Geneious Prime (2019.2.1). The 18S rRNA alignment comprised 136 OTUs (operational taxonomic units)/1,758 positions, while $\mathrm{rbcL}$ included 77 OTUs/872 positions. To perform the phylogenies, in both markers, the substitution parameter-rich model, GTR + I + G was used (Abadi et al., 2019). The maximum-likelihood phylogenies were performed in IQ-TREE Web Server (Trifinopoulos et al., 2016) considering statistical support values of ultrafast bootstrapping $(10,000$ replicates). Additional support values based on Bayesian posterior probabilities were obtained in MrBayes 3.2.7a x 64 (Ronquist et al., 2012) with sequence data set divided by codon positions. Two runs of the Markov Monte Carlo chain (MCMC) were carried out for twenty million generations each with one single cold chain and three heated chains being used in the GTR + I + G evolutionary model. The trees were sampled every 100 generations. After $10^{6}$ generations the mean standard deviation of the divided frequencies fell below 0.006 and the potential downscaling factor (PSRF) approached 1,000-1,001 for the diagnostic convergence parameters. The final trees of

${ }^{1}$ https://www.geneious.com 


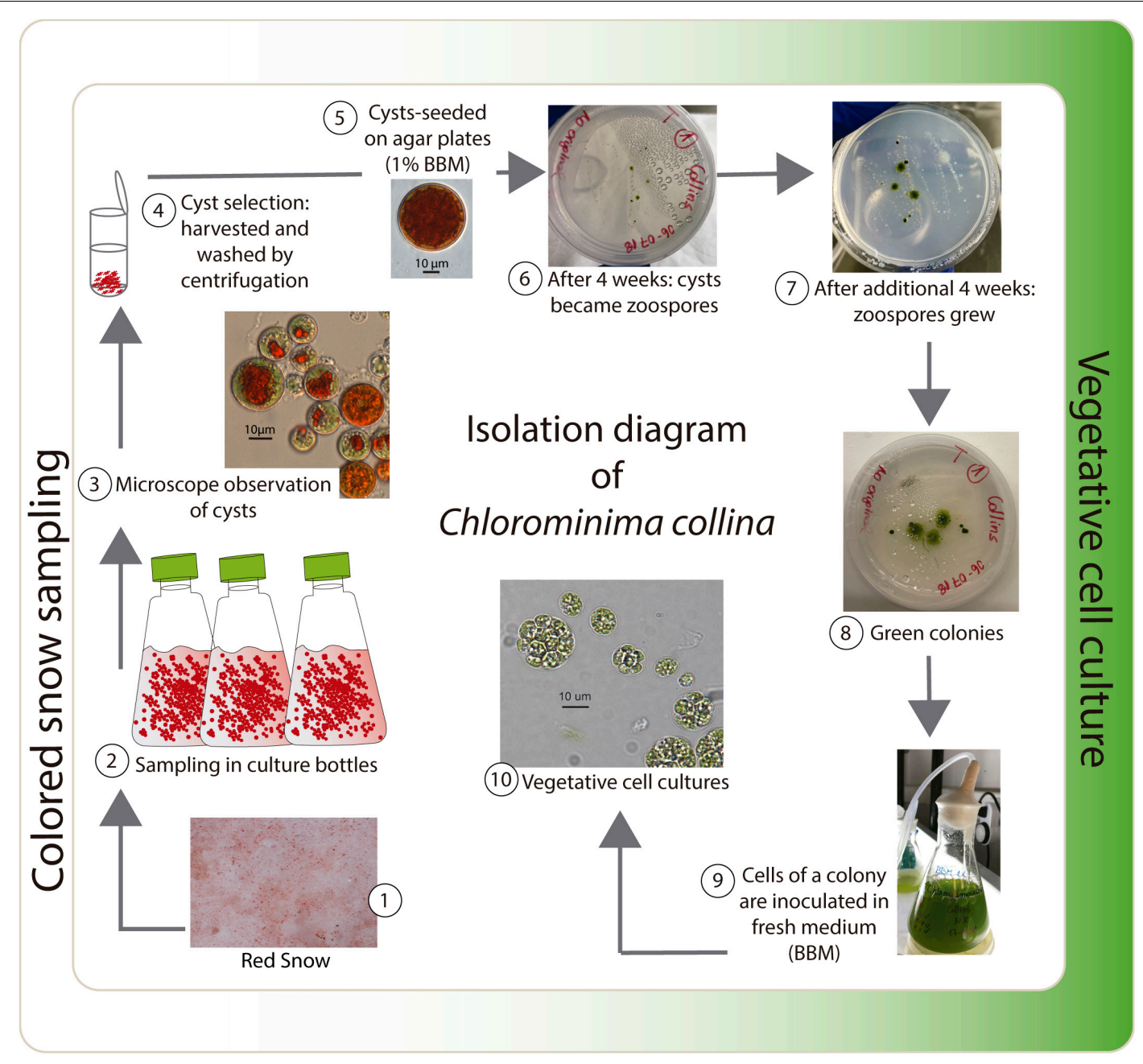

FIGURE 1 | Isolation diagram of Chlorominima collina CCAP 6/1.

IQ-TREE and MrBayes were observed in the FigTree v1.4.4 (Rambaut and Drummond, 2018).

\section{Secondary Structure Analysis of ITS2 rDNA}

The annotation of the secondary structure of the ITS2 rDNA nuclear region (including the 5.8 and $28 \mathrm{~S}$ flanking regions) of the new strain and only a few sequences of ITS2 of strains closely related obtained by BLAST algorithm (Altschul et al., 1990) was performed through the web server ${ }^{2}$ based on hidden Markov models (Keller et al., 2009), in conjunction with the ITS2 database (Schultz et al., 2006; Selig et al., 2008; Koetschan et al., 2010, 2012). Secondary structure of the annotated ITS2 sequences was predicted in RNAfold WebServer ${ }^{3}$ considering the minimum energy secondary structure and centroid secondary structure model of ITS2 (Hofacker, 2003) and then visualized by VARNA 3.93 (Darty et al., 2009).

${ }^{2} \mathrm{http}: / /$ its2.bioapps.biozentrum.uni-wuerzburg.de

${ }^{3}$ http://rna.tbi.univie.ac.at/cgi-bin/RNAWebSuite/RNAfold.cgi
Finally, a sequences-structures alignment, including the five very close sequences [Chloromonas sp. CCCryo257-06 (HQ404888), Chloromonas sp. CCCryo244-06 (HQ404887), Chloromonas sp. CCCryo273-06 (HQ404890); Chloromonas perforata CCAP 11/43 (FR865585) and Chlamydomonas applanata CCAP 11/9 (FR865616)], was built with the ClustalW2 1.83 algorithm from 4SALE 1.7.1 (Seibel et al., 2006, 2008). This program was also used to detect compensatory base changes (CBCs) between the sequences-structures (Wolf et al., 2013). The alignment obtained in 4SALE was exported to build a neighborjoining tree (Saitou and Nei, 1987) in MEGA X (Kumar et al., 2018). The evolutionary distances were computed using the Jukes-Cantor method (Jukes and Cantor, 1969). A matrix plot of CBCs was performed in PAST 4.03 software (Hammer et al., 2001).

\section{Determination of Thermal Thresholds}

To confirm the psychrophilic or psychrotrophic characteristics of the new strain, an experiment considering three temperatures $\left(2,10\right.$, and $\left.20^{\circ} \mathrm{C}\right)$ was performed. After counting in a Neubauer 
chamber, suspensions of 400,000 cells/mL ( $2 \mathrm{ml})$ of culture were inoculated in 24-well cell culture plates (Thermo Fisher Scientific, United States). To avoid evaporation and contamination, the microplates were sealed with parafilm. The microplates (24 replicates) were left for $12 \mathrm{~h}$ at their control temperature $\left(2^{\circ} \mathrm{C}\right)$. Subsequently they were transferred to acclimatization chambers for 19 days, under illumination conditions of $20-30 \mu \mathrm{mol} \mathrm{m}{ }^{-2}$ $\mathrm{s}^{-1}$ and 16:8 $\mathrm{h}$ L:D regime. Growth was measured as changes in in vivo relative fluorescence units (RFU) in a microplate reader (Varioskan Flash, Thermo Fisher Scientific, United States). Fluorescence was measured at excitation ( $\lambda$ ex $=435 \mathrm{~nm}$ ) and emission $(\lambda \mathrm{em}=685 \mathrm{~nm})$ wavelengths. The specific growth rate $(\mu)$ was calculated using the equation:

$$
\mu=\ln \left(N_{2} / N_{1}\right) /\left(t_{2}-t_{1}\right)
$$

where $\mathrm{N}_{1}$ and $\mathrm{N}_{2}$ are the growth (RFU) at time $1\left(t_{1}\right)$ and time 2 $\left(t_{2}\right)$, respectively.

The maximum quantum yield of chlorophyll fluorescence of dark-adapted photosystem II $\left(\mathrm{F}_{v} / \mathrm{F}_{m}\right)$ was measured with an Imaging-PAM fluorometer (Walz, Effeltrich, Germany). The saturation pulse method was used to determine the basal $\left(\mathrm{F}_{0}\right)$ and maximum $\left(\mathrm{F}_{m}\right)$ fluorescence performance of darkadapted samples (10 $\mathrm{min}$ is sufficient in dense microalgal mass cultures). Simultaneously, samples $(100 \mu \mathrm{L})$ were taken for the qualitative detection of reactive oxygen species (ROS) on the third day of treatment when a decrease in $\mathrm{F}_{v} / \mathrm{F}_{m}$ values was observed in the treatment at $20^{\circ} \mathrm{C}$, indicating stress or photoinhibition. To compare ROS production, samples were examined at $2^{\circ} \mathrm{C}$ (control) and at $10^{\circ} \mathrm{C}$. The in vivo production of ROS was examined using the CellROX ${ }^{\circledR}$ Green fluorogenic probe (Thermo Fisher Scientific, United States) according to a previously described protocol (Cornejo-Corona et al., 2016). For the visualization of intracellular ROS, the fluorescence was observed in an Olympus BX51 epifluorescent microscope (Olympus Corporation, Tokyo, Japan). Photographs were taken with a QImaging MicroPublisher 5.0 digital camera and the QCapture Pro-6.0 microimaging software was used for image processing.

\section{Statistical Analysis}

To examine how temperature and time influence RFU and $\mathrm{F}_{v} / \mathrm{F}_{m}$ signals, generalized linear mixed models (GLMM) (Breslow and Clayton, 1993) were performed. Temperature was considered in the analysis as a fixed factor with three levels (2, 10, and $20^{\circ} \mathrm{C}$, considering $2^{\circ} \mathrm{C}$ as a control). Time was also considered as a fixed factor. In all the models, ID of individual microalgae was incorporated as a random effect. The models that examine $\mathrm{F}_{v} / \mathrm{F}_{m}$ were based on Beta distribution, using "logit" as the link function. In the case of the models that evaluate growth by in vivo fluorescence (RFU), a Gamma distribution was considered, using " $l o g$ " as the link function. All the statistical modeling was carried out in the $\mathrm{R}$ program version 3.5.2 ( $\mathrm{R}$ Core Team, 2018), using the glmmTMB (Brooks et al., 2017) and $\operatorname{lm} 4$ (Bates et al., 2015) packages. Model comparisons were made using Akaike Information Criterion (AIC) applied within the bbmle (Bolker and Team,
2017) and MuMIn (Barton, 2019) packages. To examine how much variation is explained by the models ( $R^{2}$ coefficients), functions of the performance packages (Lüdecke et al., 2020) and MuMIn (Barton, 2019) were used. The assumptions of the fitted models were evaluated with DHARMa package (Hartig, 2020). Subsequently, a post hoc Tukey test was performed on the best models fitted with the multcomp package (Hothorn et al., 2008) and emmeans (Lenth, 2019). Multiple comparisons were applied to analyze differences between the temperature treatments, as a function of the mean time. Significance was examined at the $5 \%$ level.

\section{RNA Isolation, Library Preparation and Sequencing}

Samples of the isolated strain cultured at $2^{\circ} \mathrm{C}$ (total $30 \mathrm{ml}$ ) were centrifugated at $4,500 \times g$ for $10 \mathrm{~min}$ at $4^{\circ} \mathrm{C}$. The cell pellets were immediately frozen in liquid nitrogen and subsequently stored at $-80^{\circ} \mathrm{C}$ until further RNA extraction. The total RNA of the frozen cells was extracted and purified from $100 \mathrm{mg}$ of cell powder, according to the protocols of the SpectrumTM Plant Total RNA kit (Sigma-Aldrich). The RNA concentration was quantified by Qubit 3.0 Fluorometric Quantification (Thermo Fisher Scientific) and its integrity $($ RIN $=9.8)$ evaluated by Fragment AnalyzerAdvanced Analytical Technologies, Inc., (AATI) and Agilent DNF-471RNA kit. The library was prepared taking $4 \mu \mathrm{g}$ of RNA sample. To isolate the mRNA, molecules containing polyA, poly-T-oligo attached magnetic beads (Illumina) were used. Then the mRNA was purified and fragmented (200-700 nt) by divalent cations at $94^{\circ} \mathrm{C}$ for $5 \mathrm{~min}$. The purified mRNA was used for the construction of the cDNA library using the KAPA Stranded RNA-Seq Library Preparation Kit Illumina ${ }^{\circledR}$ Platforms. Fragment analyzer system was used to evaluate the quality of the library. The libraries obtained were sequenced in Illumina Nextseq550 at the ChileGenómico research center (Facultad de Medicina, Universidad de Chile). After sequencing, the output was transformed by base-calling into sequences, which is the "raw reads" output in fastq format. All reads have been uploaded in the Sequence Read Archive (SRA) at NCBI, under accession numbers PRJNA698241 and BioProject: SAMN17709520.

\section{Analysis, de novo Transcriptome Assembly and Annotation}

The raw reads were filtered to eliminate low quality regions (Quality score $\geq 30$ ), in the prinseq-lite software (Schmieder and Edwards, 2011). Thus, pair-end reads with primer or adapter sequences and reads with more than $10 \%$ of the bases under the established quality were removed. After the read cleaning, de novo assembly was performed using the Trinity program (Grabherr et al., 2011). The functional annotation of the assembled sequences was performed using BLAST algorithm (E-value of $<10-5$ ) against the databases: UniProt (UniProt Consortium, 2019), GO (Ashburner et al., 2000), and NCBI nonredundant protein database (NR) (Deng et al., 2006). To generate the gene ontology (GO) assignments, the Blast2GO program was applied (Conesa et al., 2005; Götz et al., 2008). 


\section{RESULTS}

\section{Morphological and Ultrastructural Features}

Light microscopy revealed the presence of vegetative cells of ellipsoidal or ellipsoidal-cylindrical shape with rounded or even spherical posterior end, of 9-11 $\mu \mathrm{m}$ long and 6-12 $\mu \mathrm{m}$ width. Figure 2, with a smooth but noticeable cell wall and a discrete, hemispherical papilla (Figure 3). Two flagella, located apically, of equal length, $1.0 \times$ cell length or longer, emerged under the papilla. TEM micrographs corroborate the presence of flagella with a cross section showing the axonema (Figure 3F). The young cells presented a single parietal chloroplast (dorsal side of the cell), laminated, shaped like a $\mathrm{C}$, which occupies a large part of the cell volume. Eyespots were not observed in all stages of the vegetative phase, nor pyrenoids, but small grains of starch were distinguished, which were dispersed between the intertylakoidal spaces, along the chloroplast (Figure 3A). The size of the starch grains increases in cells from old cultures (Figure 3G). In mature cells it is possible to note how the chloroplast partially surrounds the nucleus (Figure 3B) until cell division occurs. Therefore, this alga reproduces asexually by forming two (Figures 3C-E) to eight motile zoospores (sometimes ten zoospores can be formed, even up 16). Motility was observed when the aliquots of the mother culture were transferred to a fresh medium, similar as has been reported for Chloromonas arctica (Barcytè et al., 2018a). However, unlike Chloromonas arctica, in Chlorominima collina motility was only maintained at low temperatures. A single nucleus was observed, which was located in the posterior region of the cell, eccentric, rather lateral (Figure 3A). In addition, in young cells, a wide periplasmic space was noted. Several cytoplasmatic globular vacuoles were observed, which can be empty or containing electron-dense deposits. Large oil droplets were evident only in cells from old cultures (Figure 3G). In these cells, plastoglobuli were also noted in the chloroplast (Figure $3 \mathbf{H}$ ).

\section{Molecular Phylogeny and Secondary Structure Analysis of ITS2}

Chlorominima $(\mathrm{Cm}$.) collina was located within clade $\mathrm{C}$, one of the four main lineages identified for the Chloromonas (Cr.) and Chlamydomonas (Cd.) complex (Buchheim et al., 1997; Hoham et al., 2002). Specifically, Cm. collina is assigned within the Stephanosphaerinia phylogroup, which is one of the 21 monophyletic groups recognized for the class Chlorophyceae, order Chlamydomonadales (Nakada et al., 2008). In the phylogeny of the rbcL gene (Figure 4) the new
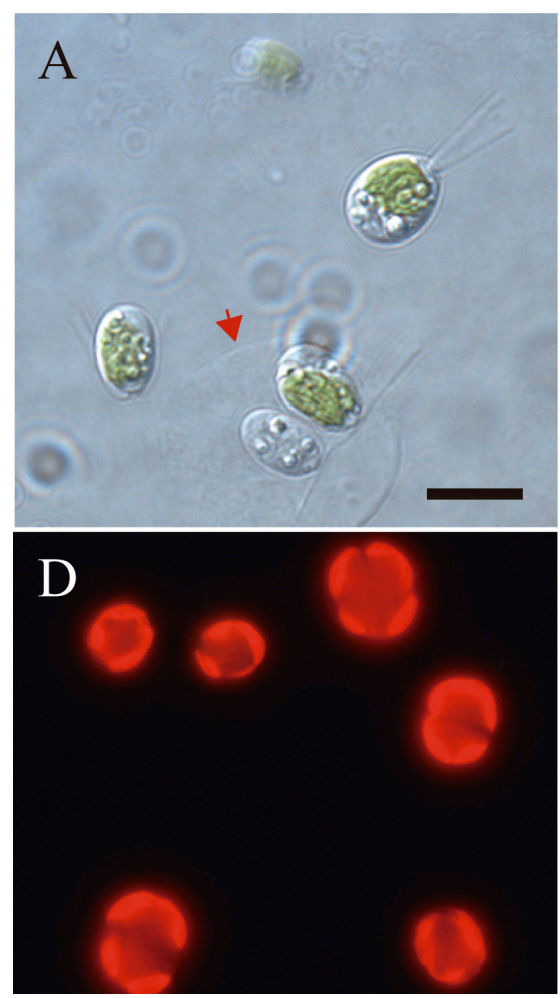
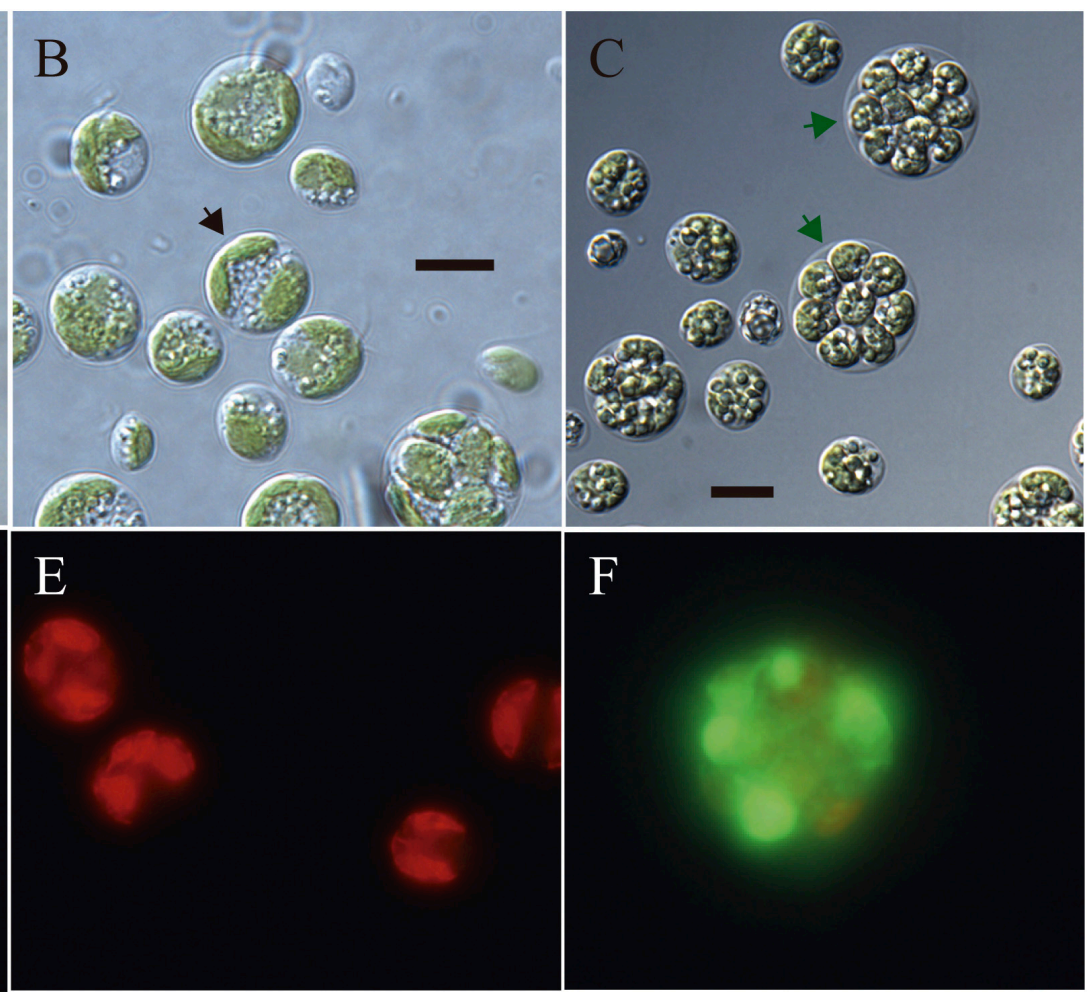

FIGURE 2 | (A-C) Light microscopy images of morphology of Chlorominima collina CCAP 6/1 (A) Zoospores with two flagella of equal length. The red arrow indicates the maternal cell wall, from which the zoospores emerged. (B) Vegetative cells in the process of cell division. Black arrow points to a cell in division. (C) Mature cells with higher amounts of starch grains and lipid droplets. Green arrows indicate zoospores within mother cell wall. (D-F) Fluorescence images of Chlorominima collina using CellROX Green dye for detection of ROS in vivo on the third day of exposure at the control temperature of $2^{\circ} \mathrm{C}$ (D) and at the treatment temperatures of $10^{\circ} \mathrm{C}(\mathbf{E})$ and $20^{\circ} \mathrm{C}(\mathbf{F})$. In panels $(\mathbf{D}, \mathbf{E})$ red stained chloroplasts of dividing cells are observed and in panel $(\mathbf{F})$ the dividing cell $(\geq 4$ zoospores) is almost completely stained green. Scale bars: $10 \mu \mathrm{m}$. 

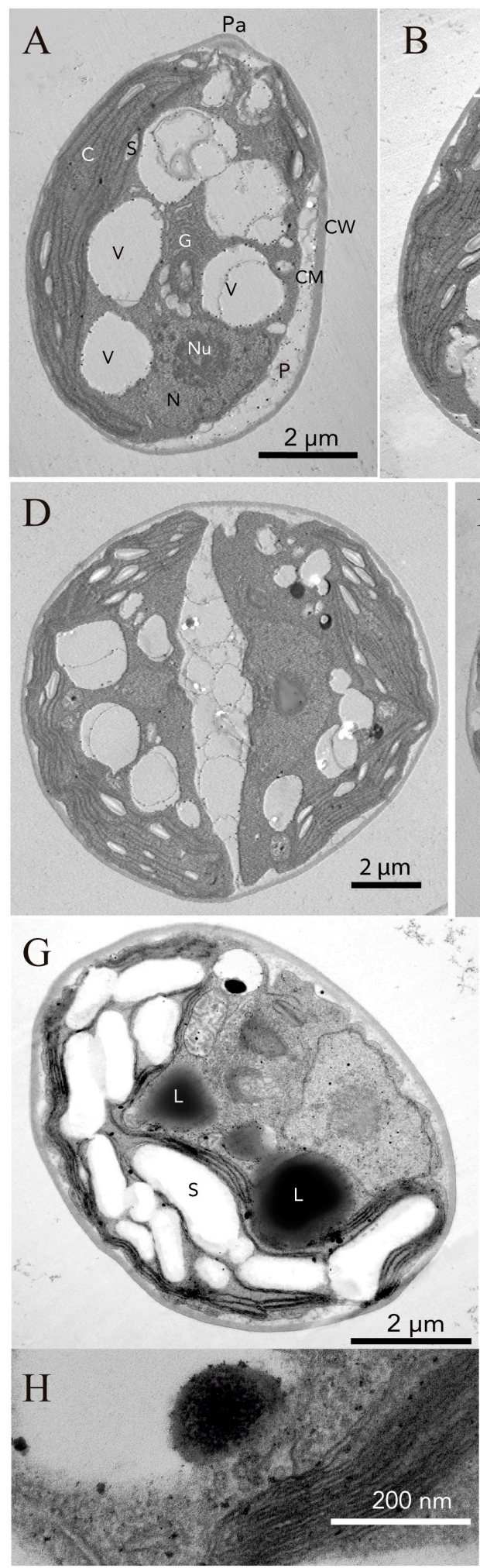
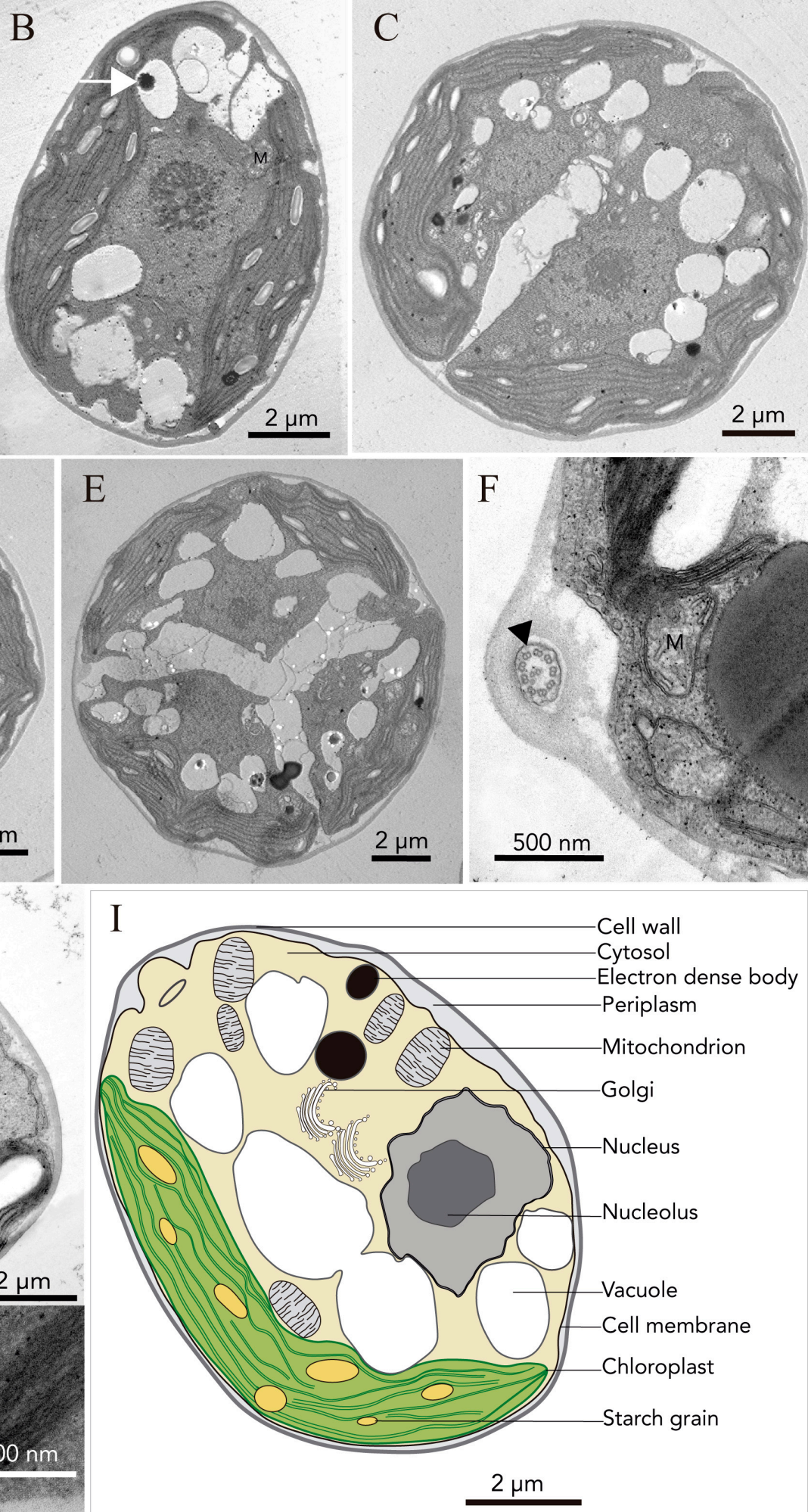

FIGURE 3 | Ultrastructure (TEM) of Chlorominima collina CCAP 6/1 (A) Longitudinal section of a zoospore. (B) Mature vegetative cell (white arrow: electron dense body). (C-E) Zoospores in the process of cell division, where the protoplast is divided transversely. (F) Cross section of the flagellum showing the $9+2$ axonema structure (black arrow). (G) Old culture cell. Pa, papilla; C, chloroplast; S, starch grains; V, vacuole; N, nucleus; Nu, nucleolus; G, Golgi apparatus; P, periplasm; CM, cell membrane; CW, cell wall; M, mitochondria; L, lipid droplet. (H) Plastoglobule in the chloroplast. (I) Consensus schematic drawing of a vegetative cell of $\mathrm{Cm}$. collina. 


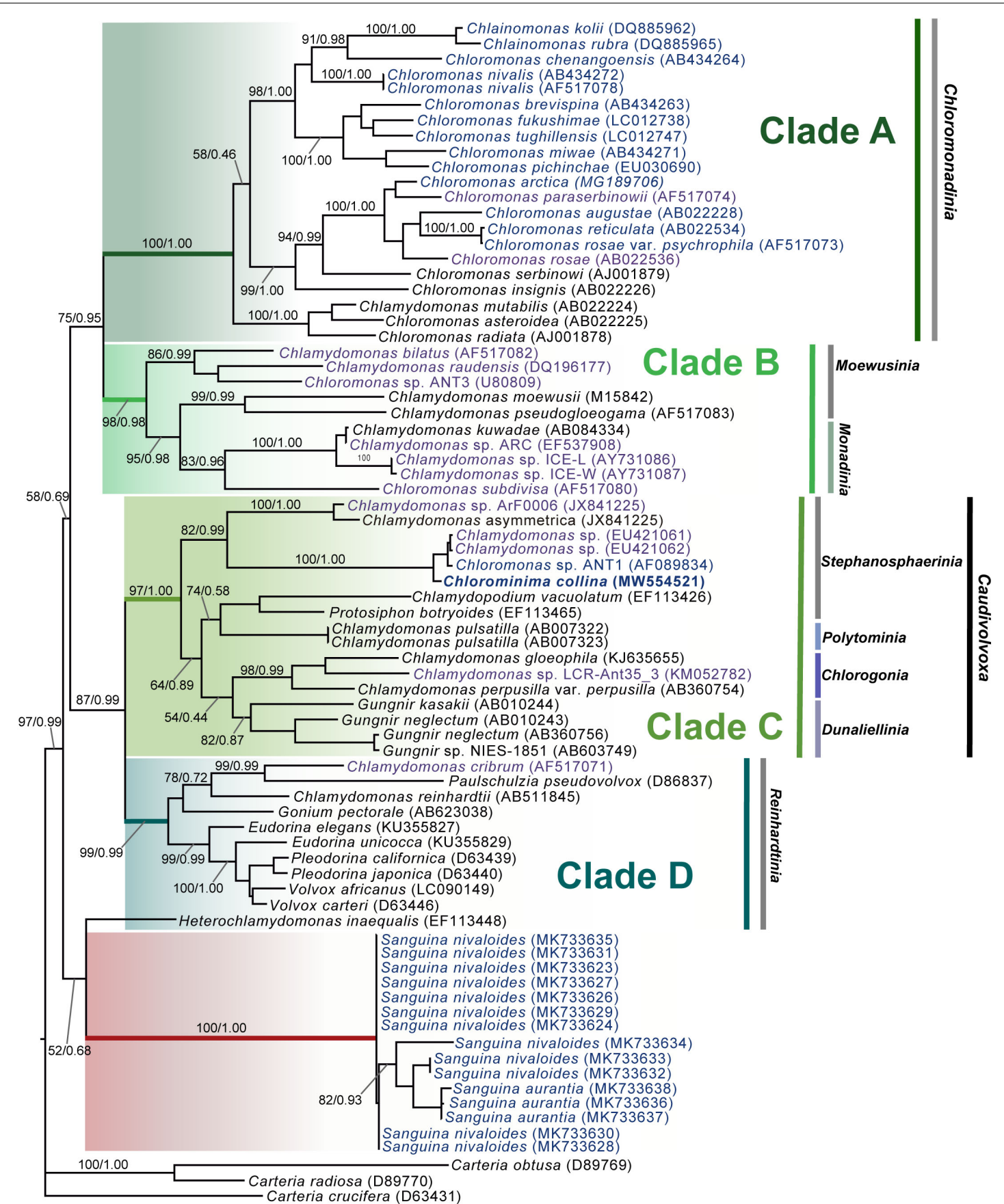

Temperate Cold Snow

FIGURE 4 | Maximum-likelihood phylogram of rbcL gene sequences. The position of Chlorominima collina CCAP 6/1 and other related members of the order Chlamydomonadales. Clades A, B, C, and D were delimited according to Hoham et al. (2002). The names of the clades were designated according to Nakada et al. (2008). The new genus of Sanguina snow algae is specified (Procházková et al., 2019a). Representatives of the genus Carteria were used as outgroup. The numbers on the branches indicate statistical support values (Maximum-likelihood bootstraps/Bayesian posterior probabilities). Snow taxa are marked in blue, taxa from other cold environments, not from snow, are marked in purple and the rest of the taxa from other temperate environments are written in black. The lower bar indicates changes by nucleotide position (0.03).

strain is located with high support [Maximum likelihood support (ML): 100/Bayesian inference (BI): 1.00] within clade $C$, in a subclade that contains unidentified polar strains assigned to the genus Chloromonas and Chlamydomonas. In this subclade, Cm. collina is more similar to the $\mathrm{rbcL}$ gene sequences of Genbank of Chloromonas sp. ANT1 (AF089834) 
and Chlamydomonas sp. CCMP681 (EU421062 and EU421061) of which it differs by 11 nucleotides. Compared with other similar rbcL gene sequences, Cm. collina differs by 90 and 98 nucleotides from Chlamydomonas gloeophila UTEX_607 (KJ635655) and Chlamydomonas pulsatilla CCAP11-106 (AB007322), respectively. Phylogenetic analyses based on $18 \mathrm{~S}$ rRNA gene corroborated the assignment of $\mathrm{Cm}$. collina in the Stephanosphaerinia phylogroup (Figure 5), where it also forms a subclade highly supported (ML: 100/BI: 1.00), with other unidentified polar strains assigned to Chloromonas and Chlamydomonas. Cm. collina presents $100 \%$ identity to the $18 \mathrm{~S}$ rRNA gene sequence of Chloromonas sp. KNF0032 (KU886306) and differs by two nucleotides from Chloromonas sp. CCCryo273-06 (HQ404890) and from Chlamydomonas sp. CCMP681 (EF106784). The secondary structure analyses of the ITS2 rDNA revealed a high similarity between $\mathrm{Cm}$. collina and strains of Chloromonas sp. (CCCryo273-06, CCCryo24406, and CCCryo257-06) with identity of 99.6-100\%. These sequences did not show CBCs (Figure 6). Other strains with similar ITS2 sequences were Chloromonas perforata CCAP 11/43 and Chlamydomonas applanata CCAP 11/9, which are representatives of Caudivolvoxa and differ from $\mathrm{Cm}$. collina by 1-5 CBCs, respectively, presenting an identity percent of 80.6 and 78.5, respectively (Figure 6).

\section{Thermal Responses of Chlorominima collina}

The isolated alga tolerates only temperatures $<10^{\circ} \mathrm{C}$ (Figure 7), while at $20^{\circ} \mathrm{C}$ declines in growth (based RFU values) and in the specific growth rates (Supplementary Figure 1) were observed. Preliminary tests indicated that the optimum growth temperature for $\mathrm{Cm}$. collina is around $4^{\circ} \mathrm{C}$ (results not shown). Low $\mathrm{F}_{v} / \mathrm{F}_{m}$ values indicated that temperatures of $20^{\circ} \mathrm{C}$ in interaction with time were stressful to photochemistry of Cm. collina (glmmTMB; $p<0.001$; Supplementary Table 1 and Figure 7B). In fact, after 3 days at $20^{\circ} \mathrm{C}, \mathrm{F}_{v} / \mathrm{F}_{m}$ reached values close to 0.1 , which was accompanied by the in vivo detection of ROS (Figure $2 \mathrm{~F}$ ). This caused a significant decrease in growth (RFU) at $20^{\circ} \mathrm{C}$ over time (glmer; $p<0.001$; Supplementary Table 1 and Figure 7A). Conversely, $\mathrm{Cm}$. collina cells kept under control temperature $\left(2^{\circ} \mathrm{C}\right)$ showed active growth (Figure 7A) and high levels of photochemical activity $\left(\mathrm{F}_{v} / \mathrm{F}_{m}\right.$ values $\leq 0.6$; Figure $\left.7 \mathrm{~B}\right)$, while in vivo ROS was not detected (Figure 2D). Interestingly, the new strain maintains relatively constant $\mathrm{F}_{v} / \mathrm{F}_{m}$ and growth values during the first days at $10^{\circ} \mathrm{C}$ (Figure 7) and ROS formation was not evident on the third day at this temperature (Figure 2E). After this period, a decline in $\mathrm{F}_{v} / \mathrm{F}_{m}$ and growth was observed, suggesting that $10^{\circ} \mathrm{C}$ is a thermal tolerance limit for $\mathrm{Cm}$. collina.

\section{De novo Transcriptome Assembly and Annotation}

In total, 2,670,333 crude Ilumina PE readings were obtained. Following removal of low-quality readings and with adapters, $1,539,352$ readings were obtained. These RNA-seq reads were subjected to a de novo transcriptome assembly, which yielded 37,401 transcripts with N50 of 881 bp and an average length of 643.88 bp (Table 1). A number of annotated sequences $(10,676)$ had a significant hit identified by BLAST search against Uniprot and NCBI, 79\% of these hits were assigned to sequences of green algae (Chlorophyta), mainly members of the Chlamydomonadales order, while the rest corresponded to other divisions of algae (Figure 8). From the annotations against the GO database, it was possible to infer the presence of genes in the categories of GO (Figure 9). In the category "biological process" the top GO terms were "cellular process" (GO: 0009987), "metabolic process” (GO: 0008152), and “cellular metabolic process" (GO: 0044237). For "molecular function" the top GO terms were "catalytic activity" (GO: 0003824) and "binding" (GO: 0005488). In the "cellular component" category, the GO terms "cellular anatomical entity" (GO: 0110165) and "intracellular" (GO: 0005622) were the most enriched (Figure 9). Transcripts annotated against the Uniprot database using BLAST similarity, indicated well-known stress-responsive genes (Table 2), e.g., genes encoding "ABC transporters" or "calcium/calmodulin-dependent protein kinase" and "heat shock proteins." The identification of several genes related to photosynthesis such as "oxygen-evolving enhancer proteins" (e.g., TRINITY_DN6396), or "Rubisco” (TRINITY_DN13299), together with other genes involved in the translation process such as "elongation factors" (e.g., TRINITY_DN21381) and "ribosomal proteins" (e.g., TRINITY_DN10395) indicate an active metabolism of $\mathrm{Cm}$. collina at $2^{\circ} \mathrm{C}$. At least 12 transcripts (Table 3) encoding antifreeze glycoprotein and ice-binding proteins were observed. A large number of transcripts associated with biosynthesis of fatty acids, especially polyunsaturated fatty acids (PUFAs), triacylglycerol (TAG), secondary carotenoids were also identified (Table 4). Additionally, genes involved in synthesis of betaine were identified (Table 5).

\section{Taxonomic Treatment Chlorominima Gálvez gen nov.}

Type species: Chlorominima collina Gálvez sp. nov.

Etymology: the name reflects the morphological similarity with the genus Chloromonas, and in turn refers to a small cell size.

Registration: http://phycobank.org/102721

Description: ellipsoidal cells with rounded posterior end, approximately $11 \mu \mathrm{m}$ long and 12 width, with two flagella of equal length at the anterior end. A single parietal chloroplast on the dorsal side of the cell, without pyrenoids, eyespot absent, and starch grains scattered between intertylakoidal spaces. Nucleus single, positioned in the posterior region of the cell, eccentric. Smooth and noticeable cell wall. Discrete hemispheric papilla. More than five contractile vacuoles irregularly distributed on the protoplast surface. Asexual reproduction through the formation of 2-16 zoospores within the parental cell wall.

\section{Chlorominima collina Gálvez sp. nov.}

Registration: http://phycobank.org/102722

Description: vegetative cells, ellipsoidal, ellipsoidal-cylindrical or spherical with rounded posterior end, of 9-11 $\mu \mathrm{m}$ length and $6-12 \mu \mathrm{m}$ width, biflagellate with flagella of equal length (1.0 $\times$ cell length or longer). Single chloroplast, laminate and parietal in the dorsal side of the cell, defined as C-shaped, 


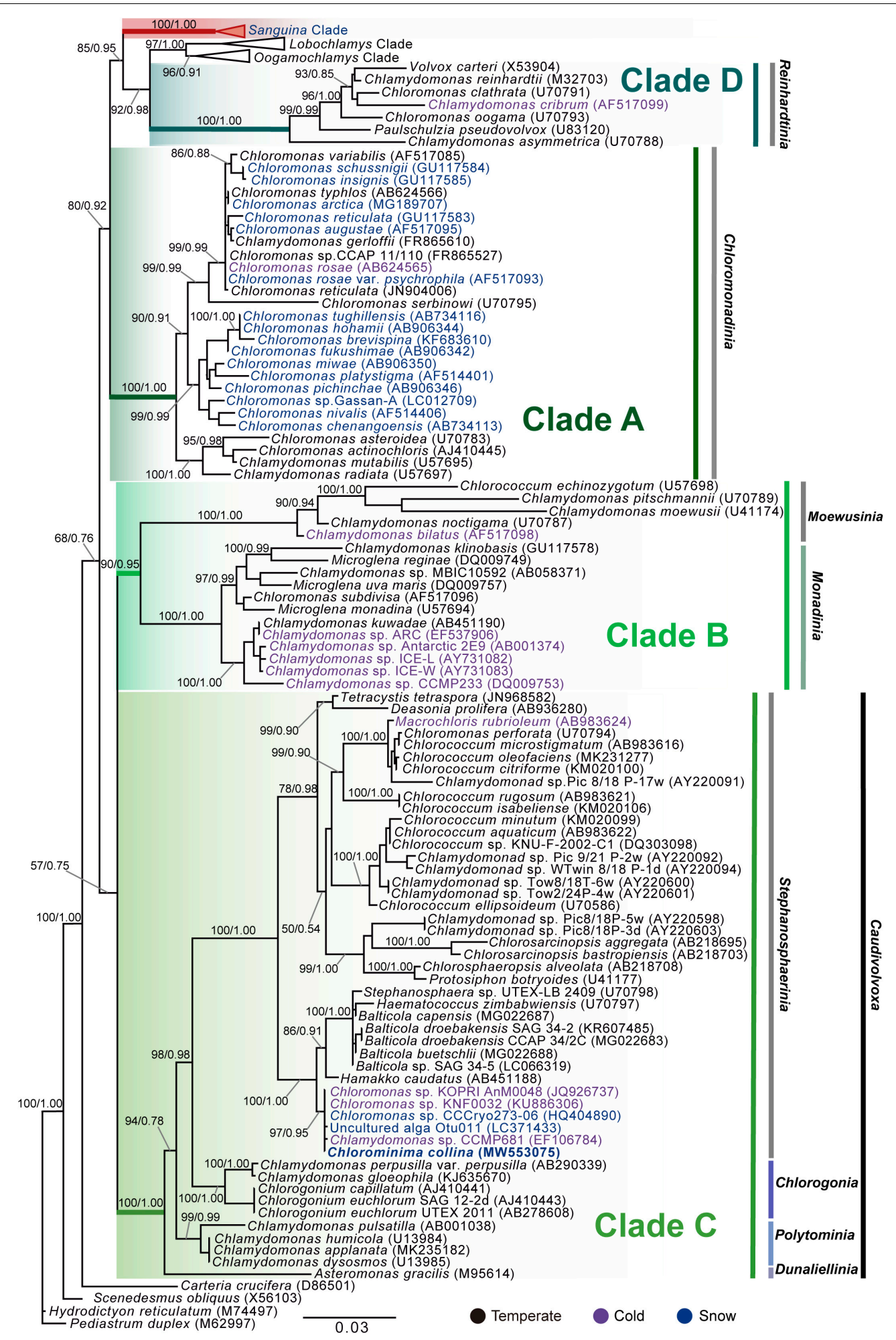

FIGURE 5 | Maximum-likelihood phylogram of the sequences of the 18S rRNA gene of Chlorominima collina CCAP 6/1 and other representative members of the order Chlamydomonadales. Clades A, B, C, and D were circumscribed according to Buchheim et al. (1997) and Hoham et al. (2002). The new genus of Sanguina snow algae is specified (Procházková et al., 2019a). Carteria crucifera, Tetradesmus obliquus, Hydrodictyon reticulatum, and Pediastrum duplex were considered as outgroup. The names of the clades were designated according to Nakada et al. (2008). The numbers on the branches indicate statistical support values (Maximum-likelihood bootstraps/Bayesian posterior probabilities). Snow taxa are marked in blue, taxa from other cold environments, not from snow, are marked in purple and the rest of the taxa from other temperate environments are written in black. The lower bar indicates changes by nucleotide position (0.03). 


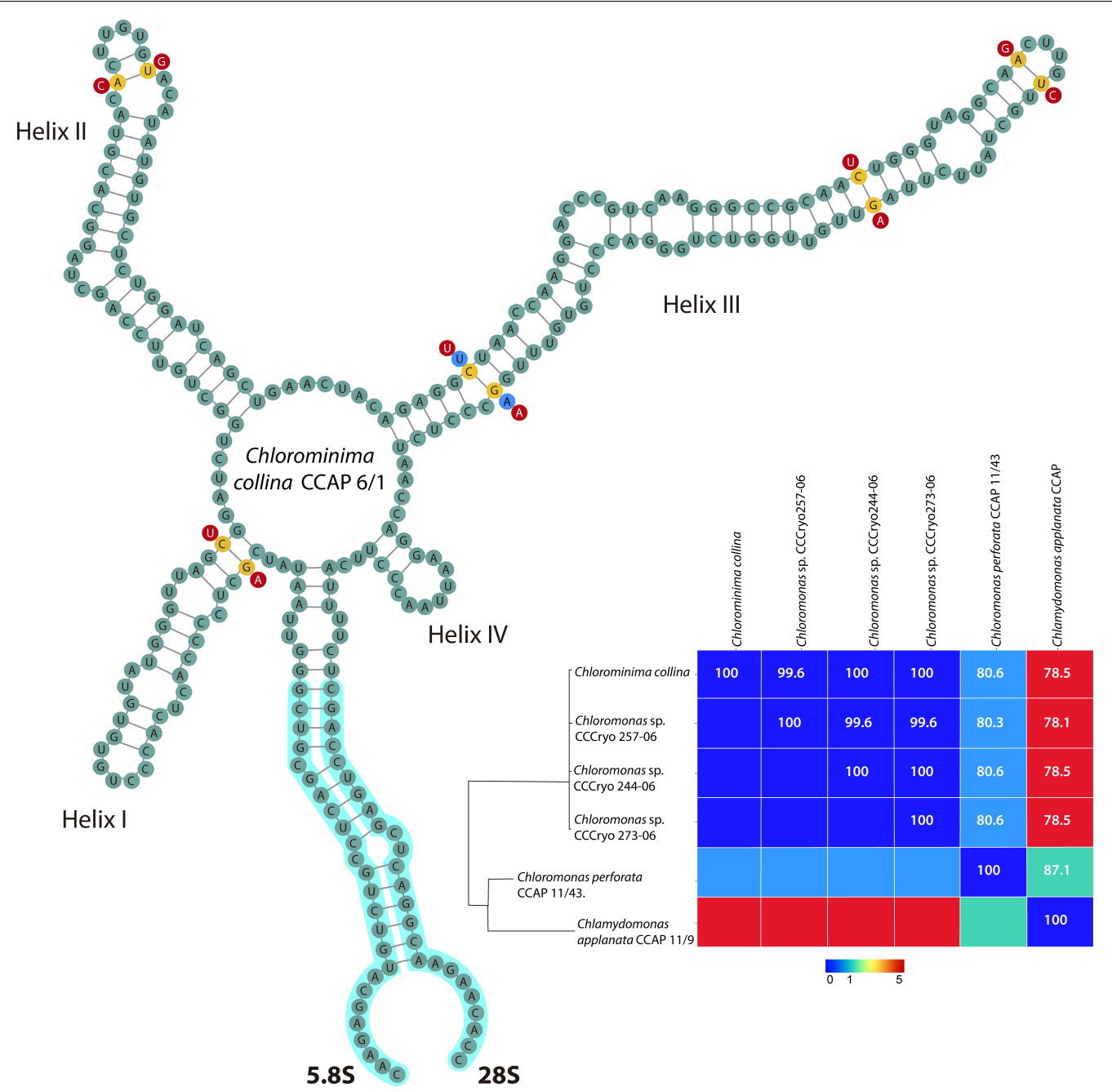

FIGURE 6 | Secondary structure model of the ITS2 rDNA of Chlorominima collina CCAP 6/1. The positions of CBC are shown in yellow circles between Chlorominima collina and Chloromonas perforata CCAP 11/43 (light blue circles) and Chlamydomonas applanata CCAP 11/9 (red circles). The Matrix under the structure shows compensatory base changes (CBCs) by color under diagonal and identity percent (above diagonal) among the respective strains considered for the analysis of the secondary structure of ITS2.

with starch grains scattered between intertylakoidal spaces. Pyrenoid and eyespot absent. Nucleus single, positioned in the posterior region of cell, eccentric, rather lateral. Approximately 5-6 contractile vacuoles distributed irregularly on the protoplast. Discrete and hemispherical anterior papilla. Young cells present wide periplasmic space. Old cells lose their flagella, are globular in shape with cytoplasmic lipid droplets that occupy most of the cell volume and increase the size of starch grains. Asexual reproduction through the formation of generally up to eight zoospores within the cell wall. In old cultures, formations of up to 16 zoospores can also be observed within the cell wall. Sexual reproduction was not evident. Cell aggregates were not observed in cultures.

Holotype: the strain is preserved permanently at $2{ }^{\circ} \mathrm{C}$ at the Photobiology Laboratory of the Universidad Austral de Chile, Valdivia, Chile. It has also been deposited in the CCAP, based in Scottish Association for Marine Science near Oban, Scotland,
United Kingdom ${ }^{4}$, under strain number CCAP 6/1. Figures 2, 3 show the morphology of the holotype.

Type locality: red snow from the Collins Glacier, King George Island, South Shetland Islands $\left(62^{\circ} 10^{\prime} 5.412^{\prime \prime} \mathrm{S}, 58^{\circ} 51^{\prime} 18.216^{\prime \prime} \mathrm{W}\right)$, Western Antarctic Peninsula.

Etymology: the species name was chosen to emphasize the holotype's sampling area, the Collins Glacier.

Distribution: Antarctica.

\section{DISCUSSION}

Recent studies have demonstrated that snow algae are taxonomically diverse. In part, this has been possible due to the application of polyphasic approaches that have allowed

\footnotetext{
${ }^{4}$ http://www.ccap.ac.uk
} 

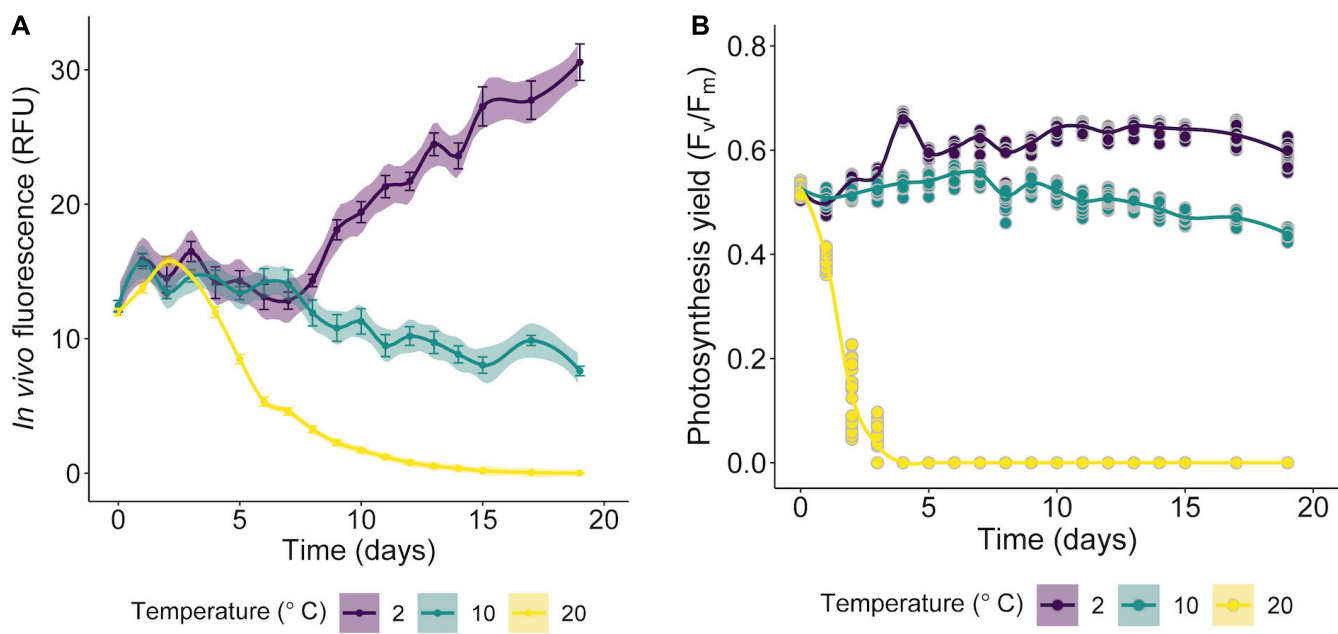

FIGURE 7 | Growth curves of Chlorominima collina CCAP 6/1 based on RFU values $(\mathbf{A})$ and efficiency of the quantum yield of photosystem II (PSII) ( $\left.F_{v} / F_{m}\right)$ (B) exposed to 2,10 , and $20^{\circ} \mathrm{C}$. The lines show the trends, and the shading indicates the confidence intervals $(\mathrm{Cl})$. In the RFU graphs, each point is the mean of 24 replicates and the bars represent the standard error (SE). For $F_{v} / F_{m}$ data, each point is an average of 24 replicates (raw data).

the identification of new species (Matsuzaki et al., 2018, 2019; Procházková et al., 2019b), even a new genus, Sanguina has been recognized as a dominant component of the snow communities (Procházková et al., 2019a). This knowledge is crucial, since it allow building a basis for characterizing the colored snow blooms, allowing to describe the genetic diversity of snow algae and their dispersal (Segawa et al., 2018; Soto et al., 2020). Thus, the description of a new Antarctic genus, Chlorominima with the species type $\mathrm{Cm}$. collina, together with the integration of molecular and physiological approaches serves not only to improve our knowledge about Antarctic taxonomic diversity, but also provides elements to understand its functional attributes, reflecting adaptations to the snow ecosystem.

New characterizations of snow communities developed in the Fildes peninsula, King George Island, have reported in the red snow a low abundance of Chloromonas sp. CCCryo273-06 (HQ404890) a integrant of the polar subclade of Chlorominima (Luo et al., 2020). This only confirms the presence of representatives of Chlorominima in the red snow, which probably coexist with members of Sanguina and Chlainomonas (Procházková et al., 2019a; Luo et al., 2020) but does not prove that the cells of Chloromonas sp. CCCryo273-06 or the isolated

TABLE 1 | Transcriptome sequencing and summary statistics of de novo assembly.

\begin{tabular}{lc}
\hline Number/length & \\
\hline Number of reads from Nextseq550 $(2 \times 150 \mathrm{pb})$ & $2,670,333$ \\
High-quality $(\mathrm{HQ})$ reads & $1,539.352$ \\
Total trinity transcripts & 37,401 \\
Total trinity genes & 33,337 \\
Percent GC & 54,82 \\
Average contig length & $643,88 \mathrm{bp}$ \\
N50 & 881
\end{tabular}

strain in this study have germinated from cysts, as a conclusive methodology it is suggested to perform single-cell sequencing, to verify the taxonomic identity of the cysts.

\section{Morphology and Ultrastructure of Chlorominima collina}

The characteristics observed in the vegetative phase of our new strain were similar to the morphological traits described for snow or ice species of Chloromonas (Ettl, 1970, 1983), including the common absence of pyrenoids. This contrasts with the presence of pyrenoids in taxa phylogenetically related to Cm. collina, such as Chlamydomonas perpusilla var. perpusilla (Nakada and Nozaki, 2007), Hamakko caudatus (Nakada and Nozaki, 2009), or Haematococcus zimbabwiensis (Buchheim et al., 2013), confirming that this structural trait may be absent or present within the Chloromonas-Chlamydomonas complex and therefore could not be relevant for the natural history of these algae (Hoham et al., 2002; Matsuzaki et al., 2012). In addition, $\mathrm{Cm}$. collina lacks an eyespot, suggesting that this structure is not an essential component of the photoreceptor apparatus (Morel-Laurens and Feinleib, 1983), which has also been reported for other snow algal strains such as Cr. pichinchae (Hoham, 1975a), Cr. krienitzii (Matsuzaki et al., 2015), or Cr. fukushimae (Matsuzaki et al., 2014). Similar to the latter species, Cm. collina has a parietal, laminate chloroplast but is defined as C-shaped, that is unusual among snow algal species of Chloromonas exhibiting a cup-shaped chloroplast (Ling and Seppelt, 1998; Matsuzaki et al., 2014, 2019). Species closely related to Cm. collina such as Hamakko caudatus (Nakada and Nozaki, 2009) also have a parietal chloroplast, it also has a similar cell width $(6-10 \mu \mathrm{m})$ to Cm. collina, but Hamakko caudatus have spindle cell shape and can have 10 contractile vacuoles and Cm. collina only 6. Other close species such as $C d$. perpusilla var. perpusilla only present two apical contractile vacuoles (Nakada and Nozaki, 2007). 


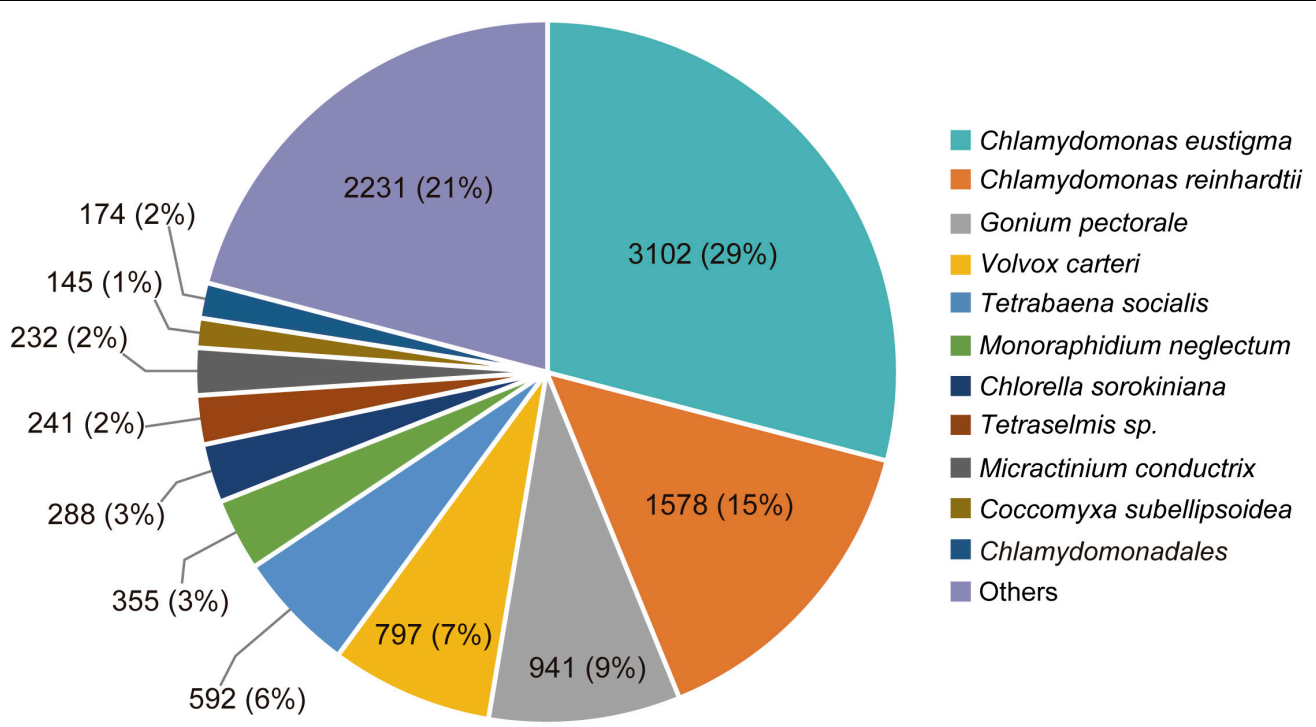

FIGURE 8 | Species distribution of the top BLAST hits by NR database annotation for Chlorominima collina CCAP 6/1. Percentage distribution of the 10 most successful species identified for each BLAST-assembled sequence against the NCBI non-redundant protein database. In addition to the percentage value, the number of genes noted per species is indicated.

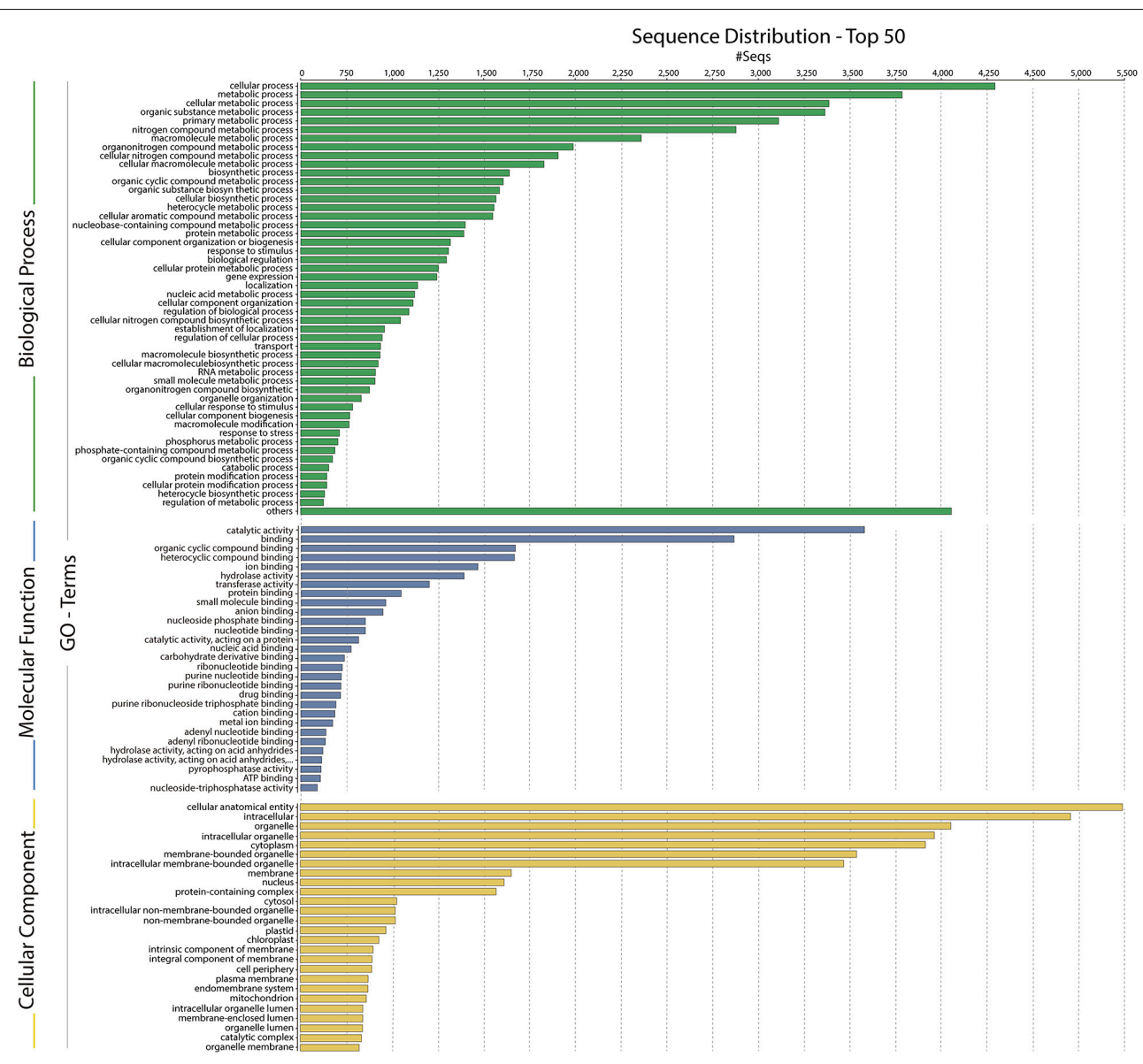

FIGURE 9 | Gene ontology (GO) assignments for the Chlorominima collina CCAP 6/1 transcriptome. Assignments generated in Blast2GO predict the participation of genes in biological processes (green); molecular functions (blue) and cellular components (yellow). 
TABLE 2 | Stress-responsive genes present in the Chlorominima collina trascriptome.

\begin{tabular}{|c|c|}
\hline De novo assembled sequence ID & GO molecular function (species) \\
\hline TRINITY_DN1216 & $\begin{array}{l}\text { ABC transporter F family member } 5 \\
\text { (Tetrabaena socialis) }\end{array}$ \\
\hline TRINITY_DN25081 & $\begin{array}{l}\text { ABC transporter B family member } 25 \\
\text { (Anthurium amnicola) }\end{array}$ \\
\hline TRINITY_DN19387 & $\begin{array}{l}\text { Leucine-rich repeat-containing protein } \\
1 \text { (Tetrabaena socialis) }\end{array}$ \\
\hline TRINITY_DN747 & $\begin{array}{l}\text { Leucine-rich repeat-containing protein } \\
40 \text { (Auxenochlorella protothecoides) }\end{array}$ \\
\hline TRINITY_DN7218 & $\begin{array}{l}\text { Hypersensitive-induced response } \\
\text { protein } 3 \text { (Tetrabaena socialis) }\end{array}$ \\
\hline TRINITY_DN6510 & $\begin{array}{l}\text { Calcium/calmodulin-dependent protein } \\
\text { kinase } 1 \text { Da (Lepisosteus oculatus) }\end{array}$ \\
\hline TRINITY_DN10034 & $\begin{array}{l}\text { Heat shock factor } 1 \text { (Chlamydomonas } \\
\text { reinhardtii) }\end{array}$ \\
\hline TRINITY_DN4825 & $\begin{array}{l}\text { Activator heat shock protein ATPase } \\
\text { (Monoraphidium neglectum) }\end{array}$ \\
\hline TRINITY_DN9027 & $\begin{array}{l}\text { Heat shock cognate } 71 \text { kDa protein-like } \\
\text { (Saccoglossus kowalevskii) }\end{array}$ \\
\hline TRINITY_DN10375 & $\begin{array}{l}\text { Heat shock protein } 70 a \text { (Dunaliella } \\
\text { salina) }\end{array}$ \\
\hline TRINITY_DN10700 & $\begin{array}{l}\text { Heat shock protein 70D } \\
\text { (Chlamydomonas reinhardtii) }\end{array}$ \\
\hline
\end{tabular}

TABLE 3 | Putative Antifreeze and Ice-Binding proteins found in transcriptome of Chlorominima collina.

\begin{tabular}{ll}
\hline De novo assembled sequence ID & Go molecular function (species) \\
\hline TRINITY_DN12789 & Antifreeze glycoprotein \\
& (Rhodosporidium toruloides) \\
TRINITY_DN1603 & Ice-binding protein-2 (Chlamydomonas \\
& sp. CCMP681) \\
TRINITY_DN1624 & Ice-binding protein-4 (Chlamydomonas \\
TRINITY_DN16614 & sp. CCMP681) \\
& Ice-binding protein-4 (Chlamydomonas \\
TRINITY_DN25734 & sp. CCMP681) \\
TRINITY_DN26347 & Ice-binding protein-4 (Chlamydomonas \\
sp. CCMP681) \\
TRINITY_DN27778 & Ice-binding protein-4 (Chlamydomonas \\
TRINITY_DN4443 & sp. CCMP681) \\
TRINITY_DN6301 & Ice-binding protein (Chloromonas sp.) \\
TRINITY_DN8708 & Ice-binding protein-4 (Chlamydomonas \\
TRINITY_DN6423 & sp. CCMP681) \\
& Ice-binding protein-4 (Chlamydomonas \\
& sp. CCMP681) \\
Ice-binding protein-4 (Chlamydomonas & sp. CCMP681) \\
Ice-binding protein-3 (Chlamydomonas & sp. CCMP681) \\
Ice-binding protein (Chloromonas sp.) \\
\hline
\end{tabular}

Furthermore, cells of $\mathrm{Cm}$. collina have an average length between 9 and $11 \mu \mathrm{m}$, while the width does not exceed $12 \mu \mathrm{m}$, resembling cells of Cr. alpina and Cr. miwae, but they differ in chloroplast and cell morphology (Matsuzaki et al., 2019). Rather, the ellipsoidal shape of the cells of $\mathrm{Cm}$. collina are comparable to Cr. hoshawii cells (Matsuzaki et al., 2018). This species does
TABLE 4 | Putative desaturases and other enzymes involved in the biosynthesis of fatty acids, triacylglycerol and secondary carotenoids present in the transcriptome of Chlorominima collina.

\begin{tabular}{|c|c|}
\hline $\begin{array}{l}\text { De novo assembled } \\
\text { sequence ID }\end{array}$ & GO molecular function (species) \\
\hline TRINITY_DN12058 & $\begin{array}{l}\text { Fatty acid elongase } 1 \text { (Orychophragmus } \\
\text { violaceus) }\end{array}$ \\
\hline TRINITY_DN12819 & Fatty acid desaturase 4 (Klebsormidium nitens) \\
\hline TRINITY_DN1377 & $\begin{array}{l}\text { Delta-12-fatty acid desaturase (Glaciozyma } \\
\text { antarctica) }\end{array}$ \\
\hline TRINITY_DN15049 & $\begin{array}{l}\text { Putative long-chain-alcohol } \\
\text { O-fatty-acyltransferase } 5 \text { (Chlorella sorokiniana) }\end{array}$ \\
\hline TRINITY_DN18272 & $\begin{array}{l}\text { Fatty acid synthase subunit alpha } \\
\text { (Rhodosporidium toruloides) }\end{array}$ \\
\hline TRINITY_DN22769 & $\begin{array}{l}\text { Cyclopropane-fatty-acyl-phospholipid synthase } \\
\text { (Tetrabaena socialis) }\end{array}$ \\
\hline TRINITY_DN27022 & $\begin{array}{l}\text { Elongation of fatty acids protein (Rhodotorula } \\
\text { graminis) }\end{array}$ \\
\hline TRINITY_DN30110 & $\begin{array}{l}\text { Putative long-chain-alcohol } \\
\text { O-fatty-acyltransferase (Tetrabaena socialis) }\end{array}$ \\
\hline TRINITY_DN6285 & Fatty acid desaturase 2 (Jatropha curcas) \\
\hline TRINITY_DN6913 & Fatty acid desaturase 5 (Theobroma cacao) \\
\hline TRINITY_DN6936 & $\begin{array}{l}\text { Fatty acid delta-6-desaturase (Lobosphaera } \\
\text { incisa) }\end{array}$ \\
\hline TRINITY_DN7069 & $\begin{array}{l}\text { Omega-3-fatty acid desaturase } \\
\text { (Chlamydomonas reinhardtii) }\end{array}$ \\
\hline TRINITY_DN6274 & $\begin{array}{l}\text { Stearoyl-ACP-desaturase (Haematococcus } \\
\text { lacustris) }\end{array}$ \\
\hline TRINITY_DN15482 & $\begin{array}{l}\text { Cytochrome P450, C-22 desaturase } \\
\text { (Chlamydomonas reinhardtii) }\end{array}$ \\
\hline TRINITY_DN9974 & $\begin{array}{l}\text { Triacylglycerol lipase-like protein } \\
\text { (Chlamydomonas reinhardtii) }\end{array}$ \\
\hline TRINITY_DN11143 & $\begin{array}{l}\text { Diacylglycerol kinase (Chlamydomonas } \\
\text { eustigma) }\end{array}$ \\
\hline TRINITY_DN18922 & $\begin{array}{l}\text { Putative phospholipid:diacylglycerol } \\
\text { acyltransferase } 2 \text { (Arabidopsis thaliana) }\end{array}$ \\
\hline TRINITY_DN19602 & $\begin{array}{l}\text { Diacylglycerol kinase (Volvox carteri f. } \\
\text { nagariensis) }\end{array}$ \\
\hline TRINITY_DN3878 & $\begin{array}{l}\text { Diacylglycerol acyltransferase type } 2 \text { (Ettlia } \\
\text { oleoabundans) }\end{array}$ \\
\hline TRINITY_DN6178 & $\begin{array}{l}\text { Diacylglycerol acyltransferase type } 2 \\
\text { (Chlamydomonas reinhardtii) }\end{array}$ \\
\hline TRINITY_DN6279 & $\begin{array}{l}\text { Glycerol-3-phosphate acyltransferase, } \\
\text { chloroplastic (Chlamydomonas eustigma) }\end{array}$ \\
\hline TRINITY_DN7159 & $\begin{array}{l}\text { 1-acyl-sn-glycerol-3-phosphate acyltransferase } \\
\text { (Chlamydomonas reinhardtii) }\end{array}$ \\
\hline TRINITY_DN7140 & $\begin{array}{l}\text { Glycerol-3-phosphate dehydrogenase [NAD(+)] } \\
\text { (Chlamydomonas reinhardtii) }\end{array}$ \\
\hline TRINITY_DN239 & $\begin{array}{l}\text { Putative stearoyl-CoA 9-desaturase } \\
\text { (Leucosporidium creatinivorum) }\end{array}$ \\
\hline TRINITY_DN10651 & $\begin{array}{l}\text { Zeta-carotene desaturase (Auxenochlorella } \\
\text { protothecoides) }\end{array}$ \\
\hline TRINITY_DN19166 & $\begin{array}{l}\text { Zeta-carotene desaturase (Haematococcus } \\
\text { lacustris) }\end{array}$ \\
\hline TRINITY_DN2370 & $\begin{array}{l}\text { Phytoene desaturase (Haematococcus } \\
\text { lacustris) }\end{array}$ \\
\hline
\end{tabular}

not present a discernible papilla and can only form up to four zoospores (rarely eight) within the parental cell wall, while $\mathrm{Cm}$. collina can form up to eight zoospores (rarely 16), a feature 
TABLE 5 | Putative betaine aldehyde dehydrogenases genes present in the transcriptome of Chlorominima collina.

\begin{tabular}{ll}
\hline De novo assembled sequence ID & Go molecular function (species) \\
\hline TRINITY_DN13477 & $\begin{array}{l}\text { Betaine aldehyde dehydrogenase 2, } \\
\text { mitochondrial (Arabidopsis thaliana) }\end{array}$ \\
TRINITY_DN21321 & $\begin{array}{l}\text { Betaine aldehyde dehydrogenase 2, } \\
\text { mitochondrial (Tarenaya hassleriana) }\end{array}$ \\
TRINITY_DN5490 & $\begin{array}{l}\text { Betaine aldehyde dehydrogenase 2 } \\
\text { (Phoenix dactylifera) }\end{array}$ \\
&
\end{tabular}

reported also in Cr. nivalis (Matsuzaki et al., 2018) and Cr. fukushimae (Matsuzaki et al., 2014). Similar to the latter species, $\mathrm{Cm}$. collina does not form cellular aggregates in cultures.

Although Cm. collina displays several typical characteristics of the Chloromonas, it is distinguished from the species described for this genus and from phylogenetically close species such as Hamakko caudatus by showing an unusual position of the nucleus, a wide periplasmic space between the inner and outer cell membranes, the presence of 5-6 contractile vacuoles, the small cell size that did not exceed $12 \mu \mathrm{m}$ in both length and width, and the absence of pyrenoid and eyespot.

\section{Phylogenetic Position of Chlorominima collina and Phylogeny of Cold Tolerant Chlamydomonadales}

Chlorominima collina CCAP $6 / 1$ is placed in the phylogroup Stephanosphaerinia, or clade C (Nakada et al., 2008). This is unexpected since most snow algae occur in clade A or Chloromonadinia (Hoham et al., 2002). Specifically, within clade $\mathrm{C}, \mathrm{Cm}$. collina forms an independent lineage, close to other polar strains unidentified, but assigned to Chloromonas and Chlamydomonas (Supplementary Table 2). With the $\mathrm{rbcL}$ gene, Cm. collina is sister to Chloromonas ANT1 and Chlamydomonas sp. CCM681, for which there are no morphological descriptions that allow comparisons, only their adaptations to cold environments have been characterized (Devos et al., 1998; Raymond et al., 2009). By using the $18 \mathrm{~S}$ rRNA gene, Cm. collina exhibits high identity with Chloromonas sp. KNF0032, both strains have a small cell size and an ovoid cell shape but differ in the shape of their chloroplasts and by the apparent presence of pyrenoid in Chloromonas sp. KNF0032 (Jung et al., 2016b). The insufficient description of Chloromonas sp. KNF0032 limits further conclusions, but it must also be taken into account that the evolutionary highly conserved $18 \mathrm{~S}$ rRNA gene does not provide sufficient resolution to discriminate between closely related species (Barcytè et al., 2018a; Remias et al., 2018; Lutz et al., 2019). When the taxonomic status of Cm. collina was verified under the CBC species concept (Coleman, 2000; Müller et al., 2007) we observe the absence of CBC among Cm. collina and other strains known as Chloromonas sp. (CCCryo27306, CCCryo244-06, and CCCryo257-06), which could indicate with a probability of $\sim 0.76$ that these algae belong to the same species (Coleman, 2000; Müller et al., 2007). This scenario may be quite feasible given the proximity between the sampling sites of these algae (Supplementary Table 2). Although, it should also be noted that even without $\mathrm{CBC}$, the named strains may belong to different species with a probability of $\sim 0.24$ (Caisová et al., 2013; Škaloud and Rindi, 2013; Procházková et al., 2018). Even in some cases it has been suggested that morphological changes precede the emergence of a CBC (Pawłowska et al., 2013). However, these strains have not been described at the species level, so there are no descriptions that allow morphological comparisons. On the other hand, the presence of $\mathrm{CBCs}$ was found in helix III, one with Chloromonas perforata CCAP 11/43 and five with Chlamydomonas applanata CCAP 11/9, revealing that $\mathrm{Cm}$. collina is a distinct taxon within Caudivolvoxa with a probability of $\sim 0.93$ (Müller et al., 2007; Wolf et al., 2013).

In the phylogenies of the $18 \mathrm{~S}$ rRNA gene and the rbcL gene it was possible to observe the four previously described clades (A, B, C, and D) for cold-tolerant taxa of Chlamydomonas and Chloromonas complex (Buchheim et al., 1997; Hoham et al., 2002), which reaffirms that these genera have colonized cold habitats at least five times during their evolutionary history (Hoham et al., 2002; Remias et al., 2010; Hoham and Remias, 2020). Additionally, by including the recent clade of Sanguina, another origin in cold habitats is added (Procházková et al., 2019a). In Stephanosphaerinia, in addition to the polar subclade of Cm. collina and related strains, there are other cold-adapted members such as Macrochloris rubrioleum CCCryo 340b-08, suggesting that there is more than one origin of cold-adaptation within of this clade. In addition, the present phylogenies show that the representatives of both Chlamydomonas and Chloromonas are not closely related, confirming the reported polyphilia of both genera (Nakayama et al., 1996; Pröschold et al., 2001; Barcyte et al., 2018a). This can be the result of a combination of factors such as the use of symplesiomorphies, environmentally variable characters, evolutionary convergence of vegetative morphologies, or maybe the omission of ecological preferences that can drive sympatric differentiation (Nakayama et al., 1996; Pröschold et al., 2001; Malavasi et al., 2016). In fact, this last point has resolved the classification of genera attaining problematic morphologies such as Coccomyxa (Malavasi et al., 2016). Interestingly, in Chloromonas-Chlamydomonas complex, the habitat has been strongly correlated with the phylogenetic history of these genera irrespective of morphology (Buchheim et al., 1997; Hoham et al., 2002; Barcyte et al., 2018b). The discovery of polar subclades in the Chlamydomonadales (Demchenko et al., 2012; Procházková et al., 2019a), such as observed in the present study, support the idea that extreme environments have promoted the evolution and speciation in unicellular chlorophytes (Pollio et al., 2005; Fučíková et al., 2014; Malavasi et al., 2016).

Considering that Cm. collina (i) forms an independent lineage within Stephanosphaerinia, (ii) it is sister to strains assigned to Chloromonas or Chlamydomonas, but which are not monophyletic with the type species of Chloromonas ( $\mathrm{Cr}$. reticulata) or Chlamydomonas ( $C d$. reinhardtii), so it is not can maintain the assigned generic identity and must be transferred to other genera (Pröschold et al., 2001), we propose a new genus Chlorominima, describing the type species Cm. collina, with the aim of generating a baseline to identify the rest of the members of 
this polar monophyletic lineage, contributing to the biodiversity of Chlamydomonadales.

\section{The Psychrophilic Character of Chlorominima collina: A Typical Feature of True Snow Algae}

Physiological experiments revealed that Cm. collina is a psychrophilic organism, therefore the increase in temperature to $20^{\circ} \mathrm{C}$ causes in this strain a marked decrease of the maximum quantum yield of the PSII and oxidative stress on the third day of exposure. These responses were also correlated with a decline in growth. Probably it was a direct result of thermal stress, which can affect key metabolic functions, disrupting cellular homeostasis and uncoupling physiological processes (Suzuki and Mittler, 2006; Barati et al., 2019). Likewise, the effects of ROS vary not only according to temperature, but also according to the duration of heat stress (Dunn et al., 2004), which in this case was in scale of days. The maintenance of growth and photosynthetic performance or $\mathrm{F}_{v} / \mathrm{F}_{m}$ during the first days of exposure to $10^{\circ} \mathrm{C}$ and the subsequent decline of these parameters may indicate that this temperature is a physiological limit for $\mathrm{Cm}$. collina similar to that observed in other snow algae (Hoham, 1975b; Devos et al., 1998). In addition to growth, the psychrophilic character was evaluated through the maximum quantum yield of PSII $\left(\mathrm{F}_{v} / \mathrm{F}_{m}\right)$, since this physiological parameter is sensitive to alterations in early photochemical reactions revealing stress (Maxwell and Johnson, 2000). These changes were observed in $\mathrm{Cm}$. collina after $24 \mathrm{~h}$ of exposure at $20^{\circ} \mathrm{C}$ with a decrease in $\mathrm{F}_{V} / \mathrm{F}_{m}$ below 0.4 compared to $\mathrm{F}_{V} / \mathrm{F}_{m}$ above 0.5 at $2^{\circ} \mathrm{C}$ (Figure $7 \mathrm{~B}$ ). Such alterations may not be detected using growth alone, so evaluating growth alone is inappropriate to define a psychrophilic organism (Feller and Gerday, 2003).

True snow algae are regarded as psychrophilic organisms that thrive exclusively in snow (Komárek and Nedbalová, 2007; Leya, 2013). This classification is valid for some algae of the genus Chloromonas such as Cr. pichinchae (Hoham, 1975a), Cr. tughillensis, and Cr. chenangoensis (Hoham et al., 2008). However, other snow isolates such as Cr. rosae v. psychrophile (Hoham et al., 2008), Cr. arctica (Barcyte et al., 2018a) and Cr. svalbardensis (Barcyte et al., 2018b) can be regarded as psychrotolerant. These algae, in contrast to true snow algae, can inhabit other substrates (e.g., soil, freshwater) (Stibal and Elster, 2005; Komárek and Nedbalová, 2007), nevertheless, under persistent cold conditions they can acquire psychrophilic adaptions (Cvetkovska et al., 2017).

The psychrophilic nature of Cm. collina is also supported by the presence of plastoglobuli in the chloroplast, which contains specialized proteomes and metabolomes to respond to abiotic stress (van Wijk and Kessler, 2017). In addition, stressors such as high doses of UV-B radiation (Tian and Yu, 2009) or sulfur deficiency (Mizuno et al., 2013) have been reported to cause an increase in starch grains. The latter was observed in old cells of Cm. collina similar to Cr. arctica (Barcytè et al., 2018a), but unlike this alga, $\mathrm{Cm}$. collina cells retain their flagella only at low temperature. When $\mathrm{Cm}$. collina cells are exposed to elevated temperatures, they lose their flagella, similar to observed in the snow algae Chlainomonas kolii and Chlainomonas rubra (Hoham, 1975b).

\section{The Transcriptome of Chlorominima collina Reflects Adaptations to the Antarctic Snow Environment}

Based on the functional annotation of the transcriptome, it is possible to identify the expression of the following groups of key genes: (i) stress-responsive genes, including genes that encode "heat shock proteins." The expression of these genes is common in polar algae and cannot only be stimulated by heat, but also by cold (Liu et al., 2010, 2016; Kim et al., 2013). In addition, we identified CaM genes or "calmodulin," whose expression is regulated by non-optimal temperature conditions, high UV-B radiation and salinity, conditions commonly found in Maritime Antarctica (He et al., 2017). Besides, the presence of genes of $\mathrm{ABC}$ transporters, linked to transport of metabolic intermediates and compounds for detoxification, as observed in other polar algae suggests a functional role in cold acclimatization (Mock et al., 2006; Liu et al., 2016; Poong et al., 2018). We also identified (ii) ice-active genes, such as genes encoding "antifreeze glycoprotein" and "ice-binding proteins" or IBPs, which have been found only in psychrophilic species (Oude Vrielink et al., 2016), particularly in snow species of the Chlamydomonadales (Leya, 2013). Therefore there are no homologs to IBPs in mesophilic species (Raymond et al., 2009; Dolhi et al., 2013). The novel IBPs discovered the Antarctic strain Chlamydomonas sp. CCMP681 showed effects on the inhibition of recrystallization and on the retention of brine in ice (Raymond et al., 2009), likewise the expression of IBP genes can also be regulated by heat (Jung et al., 2016a) and light stress (Gwak et al., 2014). The origin of these genes, whose resemblance to bacterial IBPs genes suggests the idea of a possible horizontal gene transfer (HGT), which can be facilitated by transposases (Raymond and Kim, 2012; Liu et al., 2016). Although some transposases were identified in the $\mathrm{Cm}$. collina transcriptome, (TRINITY_DN1269; TRINITY_DN2803), evidence for HGT is still not conclusive. We also observe (iii) genes encoding cryoprotectants and fatty acids such as "Omega-3-fatty acid desaturase" involved in the biosynthesis of polyunsaturated fatty acids or PUFAs (Garba et al., 2017). Since PUFAs regulate membrane fluidity, their prevalence is regarded as one of the most common adaptations of psychrophilic organisms (De Maayer et al., 2014). Likewise, the presence of "Cytochrome P450, C-22 desaturase" genes can be indicative of sterol biosynthesis that also regulates the fluidity of the membrane (Brumfield et al., 2017). Furthermore, "Diacylglycerol acyltransferase" genes involved in the biosynthesis of triacylglycerol (TAG) were found, which is related to tolerance to freezing (Zienkiewicz et al., 2016; Tan et al., 2018). The presence of "Phytoene desaturase" genes may suggest an active synthesis of secondary carotenoids (Grünewald et al., 2000), whose antioxidant activity is also induced by cold (Gocheva et al., 2009; Lemoine and Schoefs, 2010). Other genes, such as those that encode "Betaine aldehyde dehydrogenase," suggest the accumulation of betaine that reduce the freezing point in the cytoplasm (De Maayer et al., 2014). Thus, it is proposed that 


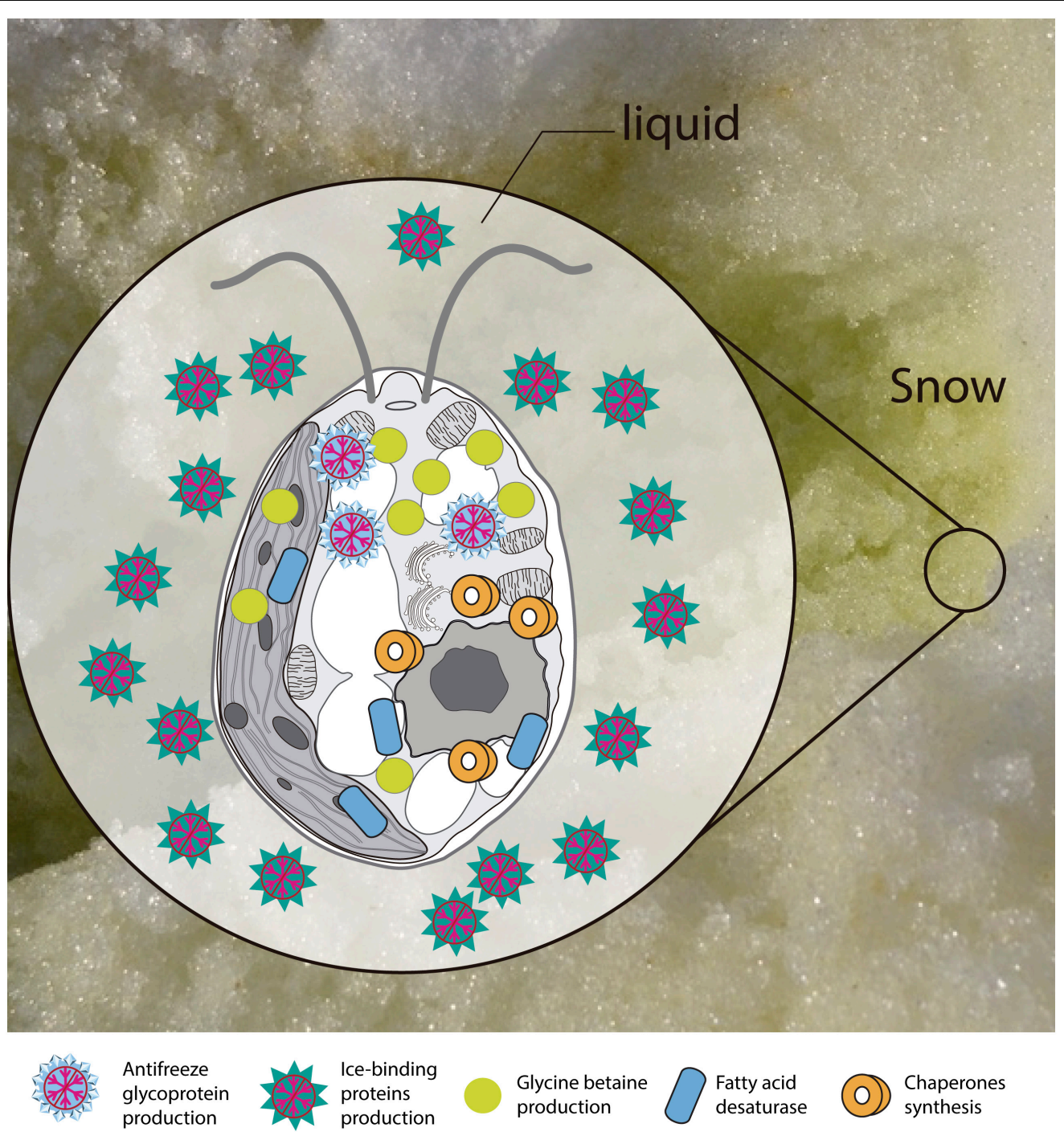

FIGURE 10 | Scheme of the main transcriptional responses at low temperature. Putative proteins and enzymes present in the Chlorominima collina CCAP 6/1 transcriptome are represented.

joint regulation of the above-mentioned genes allows $\mathrm{Cm}$. collina (Figure 10) to thrive in Antarctic snow.

\section{CONCLUSION}

Our study corroborates the suitability of using a polyphasic approach to identify and characterize snow alga $\mathrm{Cm}$. collina. This new strain presents some typical morphological features of Chloromonas-like algae but differs from this genus by the unusual position of the nucleus, the shape of the chloroplast, the number of vacuoles and the small size of the cells. The phylogenies confirm that the new alga is not Chloromonas but forms an independent lineage, sister to other strains uncertainly assigned to Chloromonas-Chlamydomonas, forming a polar subclade within Stephanosphaerinia. Within the Chlamydomonadales, $\mathrm{Cm}$. collina is proposed as a distinct taxon according to the comparisons with models of the secondary structures of the ITS2 rDNA. Based on these results, we propose a new Antarctic genus, Chlorominima with the species type Cm. collina. The integration of physiological and transcriptomic approaches revealed psychrophilic characteristics that reflect adaptations to the snow environment. Therefore, the description of $\mathrm{Cm}$. collina, improves our knowledge on the diversity of snow algae within Stephanosphaerinia.

\section{NOMENCLATURE}

\section{Resource Identification Initiative}

To take part in the Resource Identification Initiative, please use the corresponding catalog number and RRID in your current manuscript. For more information about the project and for steps on how to search for an RRID, please click here. 


\section{Life Science Identifiers}

Life Science Identifiers (LSIDs) for ZOOBANK registered names or nomenclatural acts should be listed in the manuscript before the keywords with the following format:

urn:lsid: < Authority $>$ : < Namespace $>$ : $<$ ObjectID $>$ $[:<$ Version $>]$

For more information on LSIDs please see Inclusion of Zoological Nomenclature section of the guidelines.

\section{DATA AVAILABILITY STATEMENT}

The datasets presented in this study can be found in online repositories. The names of the repository/repositories and accession number(s) can be found in the article/ Supplementary Material.

\section{AUTHOR CONTRIBUTIONS}

FEG sampled the algal material in the Antarctic, performed the isolation of the strain from cysts, and conducted the light microscopy and assisted in the electron microscopy studies. Also, carried out the physiological experiment and measurements for thermal threshold and transcriptomic analysis. $\mathrm{PH}$ supervised at the beginning the cultivation and maintenance procedures in the laboratory as well as the fluorescence techniques for growth rate measurement. AS and FEG with the help of the AUSTRALomics team and obtained the DNA sequences and performed the RNA extraction. MS-C performed the phylogenetic analyses and the sequence structure of the ITS2 rDNA. AS was in charge of the RNA library sequencing and transcriptional analysis. The first draft of manuscript was written by FEG and edited by IG. Finally, all authors contributed with inputs to the final stage of the manuscript.

\section{REFERENCES}

Abadi, S., Azouri, D., Pupko, T., and Mayrose, I. (2019). Model selection may not be a mandatory step for phylogeny reconstruction. Nat. Commun. 10:934. doi: 10.1038/s41467-019-08822-w

Altschul, S. F., Gish, W., Miller, W., Myers, E. W., and Lipman, D. J. (1990). Basic local alignment search tool. J. Mol. Biol. 215, 403-410. doi: 10.1016/S00222836(05)80360-2

Andersen, R. A. (2005). Algal Culturing Techniques. Cambridge, MA: Academic Press.

Anesio, A. M., and Laybourn-Parry, J. (2012). Glaciers and ice sheets as a biome. Trends Ecol. Evol. 27, 219-225.

Anesio, A. M., Lutz, S., Chrismas, N. A. M., and Benning, L. G. (2017). The microbiome of glaciers and ice sheets. NPJ Biofilms Microbiomes 3, 1-11.

Ashburner, M., Ball, C. A., Blake, J. A., Botstein, D., Butler, H., Cherry, J. M., et al. (2000). Gene ontology: tool for the unification of biology. Nat. Genet. 25, 25-29. doi: $10.1038 / 75556$

Barati, B., Gan, S.-Y., Lim, P.-E., Beardall, J., and Phang, S.-M. (2019). Green algal molecular responses to temperature stress. Acta Physiol. Plant. 41:26. doi: 10.1007/s11738-019-2813-1

Barcytè, D., Hodač, L., Nedbalová, L., and Elster, J. (2018a). Chloromonas arctica sp. nov., a psychrotolerant alga from snow in the High Arctic (Chlamydomonadales, Chlorophyta). Int. J. Syst. Evol. Microbiol. 68, 851-859. doi: 10.1099/ijsem.0.002595

\section{FUNDING}

This research was funded by the grants Fondecyt 1161129, Fondecyt 1201053 and Fondap IDEAL 15150003 to IG and PH, and INACh DG_12_19 to FEG.

\section{ACKNOWLEDGMENTS}

The Instituto Antártico Chileno (INACh) granted the necessary permissions to obtain snow samples in the Antarctic in accordance with the Protocol on Environmental Protection to the Antarctic Treaty and provided the logistic support at the Professor Julio Escudero scientific station during the campaign 2018-ECA54. We would like to thank Dayane Osman for her valuable technical assistance during field sampling and during laboratory work. We would also like to thank the Electron Microscopy Unit (UME) of the Universidad Austral de Chile for TEM analysis. We are grateful to Carolina Encina and Luis Guzman for helpful assistance during sequencing and library preparation at AUSTRAl-omics, and Nelson Valdivia and Cristian Molina for their help with data analysis and bioinformatics, respectively. We are also grateful for the valuable comments and criticisms of two reviewers and editor LN, who substantially improved the manuscript.

\section{SUPPLEMENTARY MATERIAL}

The Supplementary Material for this article can be found online at: https://www.frontiersin.org/articles/10.3389/fpls.2021. 662298/full\#supplementary-material

Barcytè, D., Hodač, L., Nedbalová, L., and Elster, J. (2018b). Chloromonas svalbardensis n. sp. with Insights into the Phylogroup Chloromonadinia (Chlorophyceae). J. Eukaryot. Microbiol. 65, 882-892. doi: 10.1111/jeu.12633

Barton, K. (2019). MuMIn: Multi-Model Inference. R package version 1.43.6.

Bates, D., Mächler, M., Bolker, B., and Walker, S. (2015). Fitting linear mixed-effects models using lme4. J. Stat. Softw. 67, 1-48.

Bischoff, H. W., and Bold, H. C. (1963). Some Algae from Enchanted Rock and Related Algal Species. Austin, TX: University of Texas.

Boetius, A., Anesio, A. M., Deming, J. W., Mikucki, J. A., and Rapp, J. Z. (2015). Microbial ecology of the cryosphere: sea ice and glacial habitats. Nat. Rev. Microbiol. 13, 677-690. doi: 10.1038/nrmicro3522

Bolker, B., and Team, R. C. (2017). bbmle: Tools for General Maximum Likelihood Estimation. R Package version 1.0. 19.

Breslow, N. E., and Clayton, D. G. (1993). Approximate inference in generalized linear mixed models. J. Am. Stat. Assoc. 88:9. doi: 10.2307/2290687

Broady, P. (1996). Diversity, distribution and dispersal of Antarctic terrestrial algae. Biodivers. Conserv. 5, 1307-1335. doi: 10.1007/BF00051981

Brooks, M. E., Kristensen, K., van Benthem, K. J., Magnusson, A., Berg, C. W., Nielsen, A., et al. (2017). glmmTMB balances speed and flexibility among packages for zero-inflated generalized linear mixed modeling. $R$ J. 9, 378-400. doi: 10.32614/RJ-2017-066

Brumfield, K. M., Laborde, S. M., and Moroney, J. V. (2017). A model for the ergosterol biosynthetic pathway in Chlamydomonas reinhardtii. Eur. J. Phycol. 52, 64-74. doi: 10.1080/09670262.2016.1225318 
Buchheim, M. A., Buchheim, J. A., and Chapman, R. L. (1997). Phylogeny of Chloromonas (Chlorophyceae): a study of $18 \mathrm{~S}$ ribosomal RNA gene sequences. J. Phycol. 33, 286-293. doi: 10.1111/j.0022-3646.1997.00286.x

Buchheim, M. A., Sutherland, D. M., Buchheim, J. A., and Wolf, M. (2013). The blood alga: phylogeny of Haematococcus (Chlorophyceae) inferred from ribosomal RNA gene sequence data. Eur. J. Phycol. 48, 318-329. doi: 10.1080/ 09670262.2013.830344

Caisová, L., Marin, B., and Melkonian, M. (2013). A consensus secondary structure of ITS2 in the Chlorophyta identified by phylogenetic reconstruction. Protist 164, 482-496. doi: 10.1016/j.protis.2013.04.005

Coleman, A. W. (2000). The significance of a coincidence between evolutionary landmarks found in mating affinity and a DNA sequence. Protist 151, 1-9. doi: 10.1078/1434-4610-00002

Conesa, A., Götz, S., García-Gómez, J. M., Terol, J., Talón, M., and Robles, M. (2005). Blast2GO: a universal tool for annotation, visualization and analysis in functional genomics research. Bioinformatics 21, 3674-3676. doi: 10.1093/ bioinformatics/bti610

Cook, A. J. (2005). Retreating glacier fronts on the Antarctic Peninsula over the past half-century. Science 308, 541-544. doi: 10.1126/science.1104235

Cornejo-Corona, I., Thapa, H. R., Browne, D. R., Devarenne, T. P., and LozoyaGloria, E. (2016). Stress responses of the oil-producing green microalga Botryococcus braunii Race B. PeerJ 4:e2748. doi: 10.7717/peerj.2748

Cvetkovska, M., Hüner, N. P. A., and Smith, D. R. (2017). Chilling out: the evolution and diversification of psychrophilic algae with a focus on Chlamydomonadales. Polar Biol. 40, 1169-1184. doi: 10.1007/s00300-0162045-4

Darty, K., Denise, A., and Ponty, Y. (2009). VARNA: interactive drawing and editing of the RNA secondary structure. Bioinformatics 25:1974.

De Maayer, P., Anderson, D., Cary, C., and Cowan, D. A. (2014). Some like it cold: understanding the survival strategies of psychrophiles. EMBO Rep. 15, 508-517. doi: $10.1002 /$ embr. 201338170

Demchenko, E., Mikhailyuk, T., Coleman, A. W., and Pröschold, T. (2012). Generic and species concepts in Microglena (previously the Chlamydomonas monadina group) revised using an integrative approach. Eur. J. Phycol. 47, 264-290. doi: 10.1080/09670262.2012.678388

Deng, Y. Y., Li, J. Q., Wu, S. F., Zhu, Y. P., Chen, Y. W., and He, F. (2006). Integrated $\mathrm{nr}$ database in protein annotation system and its localization. Comput. Eng. 32, 71-72.

Devos, N., Ingouff, M., Loppes, R., and Matagne, R. F. (1998). RUBISCO adaptation to low temperatures: a comparative study in psychrophilic and mesophilic unicellular algae. J. Phycol. 34, 655-660. doi: 10.1046/j.1529-8817.1998.340 655.x

Dolhi, J. M., Maxwell, D. P., and Morgan-Kiss, R. M. (2013). Review: the Antarctic Chlamydomonas raudensis: an emerging model for cold adaptation of photosynthesis. Extremophiles 17, 711-722. doi: 10.1007/s00792-013-0571-3

Dunn, S. R., Thomason, J. C., Le Tissier, M. D. A., and Bythell, J. C. (2004). Heat stress induces different forms of cell death in sea anemones and their endosymbiotic algae depending on temperature and duration. Cell Death Differ. 11, 1213-1222. doi: 10.1038/sj.cdd.4401484

Ettl, H. (1970). Die Gattung Chloromonas Gobi emend. Wille (Chlamydomonas und Die Nächstverwandten Gattungen I). Nov. Hedwigia Beihefte 34, 1-283.

Ettl, H. (1983). Chlorophyta I. Phytomonadina. Portland, OR: Gustav Fischer.

Feller, G., and Gerday, C. (2003). Psychrophilic enzymes: hot topics in cold adaptation. Nat. Rev. Microbiol. 1, 200-208. doi: 10.1038/nrmicro773

Fogg, G. E. (1967). Observations on the snow algae of the South Orkney Islands. Philos. Trans. R. Soc. Lond. B. Biol. Sci. 252, 279-287. doi: 10.1098/rstb.1967. 0018

Friedl, T. (1996). Evolution of the polyphyletic genus Pleurastrum (Chlorophyta): inferences from nuclear-encoded ribosomal DNA sequences and motile cell ultrastructure. Phycologia 35, 456-469. doi: 10.2216/i0031-8884-35-5-456.1

Fuč́ková, K., Lewis, P. O., and Lewis, L. A. (2014). Putting incertae sedis taxa in their place: a proposal for ten new families and three new genera in Sphaeropleales (Chlorophyceae, Chlorophyta). J. Phycol. 50, 14-25. doi: 10. 1111/jpy.12118

Garba, L., Shukuri Mo, M., Nurbaya Os, S., and Noor Zalih, R. (2017). Review on fatty acid desaturases and their roles in temperature acclimatisation. J. Appl. Sci. 17, 282-295. doi: 10.3923/jas.2017.282.295
Garcia-Lopez, E., and Cid, C. (2017). "The role of microbial ecology in glacier retreat," in Glaciers Evolution in a Changing World, ed. D. Godone (London: InTech), 105. doi: 10.5772/intechopen.69097

Gocheva, Y. G., Tosi, S., Krumova, E. T., Slokoska, L. S., Miteva, J. G., Vassilev, S. V., et al. (2009). Temperature downshift induces antioxidant response in fungi isolated from Antarctica. Extremophiles 13, 273-281. doi: 10.1007/s00792008-0215-1

Götz, S., García-Gómez, J. M., Terol, J., Williams, T. D., Nagaraj, S. H., Nueda, M. J., et al. (2008). High-throughput functional annotation and data mining with the Blast2GO suite. Nucleic Acids Res. 36, 3420-3435. doi: 10.1093/nar/gkn176

Grabherr, M. G., Haas, B. J., Yassour, M., Levin, J. Z., Thompson, D. A., Amit, I., et al. (2011). Full-length transcriptome assembly from RNA-Seq data without a reference genome. Nat. Biotechnol. 29, 644-652. doi: 10.1038/nbt.1883

Gradinger, R., and Nürnberg, D. (1996). Snow algal communities on Arctic pack ice floes dominated by Chlamydomonas nivalis (Bauer) Wille. Proc. NIPR Symp. Polar Biol. 9, 35-43.

Grünewald, K., Eckert, M., Hirschberg, J., and Hagen, C. (2000). Phytoene desaturase is localized exclusively in the chloroplast and up-regulated at the mRNA Level during accumulation of secondary carotenoids in Haematococcus pluvialis (Volvocales, Chlorophyceae). Plant Physiol. 122, 1261-1268. doi: 10. 1104/pp.122.4.1261

Gwak, Y., Jung, W., Lee, Y., Kim, J. S., Kim, C. G., Ju, J.-H., et al. (2014). An intracellular antifreeze protein from an Antarctic microalga that responds to various environmental stresses. FASEB J. 28, 4924-4935. doi: 10.1096/fj.14256388

Hamby, K. R., Sims, L., Issel, L., and Zimmer, E. (1988). Direct ribosomal RNA sequencing: optimization of extraction and sequencing methods for work with higher plants. Plant Mol. Biol. Report. 6, 175-192. doi: 10.1007/BF02669591

Hamilton, T. L., and Havig, J. (2017). Primary productivity of snow algae communities on stratovolcanoes of the Pacific Northwest. Geobiology 15, 280 295. doi: 10.1111/gbi.12219

Hammer, Ø, Harper, D. A. T., and Ryan, P. D. (2001). PAST: Paleontological statistics software package for education and data analysis. Palaeontol. Electron. 4:9.

Hartig, F. (2020). DHARMa: Residual Diagnostics for Hierarchical (MultiLevel/Mixed) Regression Models. R Package V. 0.3.3.0.

Havig, J. R., and Hamilton, T. L. (2019). Snow algae drive productivity and weathering at volcanic rock-hosted glaciers. Geochim. Cosmochim. Acta 247, 220-242. doi: 10.1016/j.gca.2018.12.024

He, Y., Wang, Y., Zheng, Z., Liu, F., An, M., He, X., et al. (2017). Cloning and stress-induced expression analysis of calmodulin in the Antarctic alga Chlamydomonas sp. ICE-L. Curr. Microbiol. 74, 921-929. doi: 10.1007/s00284017-1263-5

Hofacker, I. L. (2003). Vienna RNA secondary structure server. Nucleic Acids Res. 31, 3429-3431. doi: 10.1093/nar/gkg599

Hoham, R. W. (1975a). Optimum temperatures and temperature ranges for growth of snow algae. Arct. Alp. Res. 7, 13-24. doi: 10.2307/1550094

Hoham, R. W. (1975b). The life history and ecology of the snow alga Chloromonas pichinchae (Chlorophyta, Volvocales). Phycologia 14, 213-226. doi: 10.2216/ i0031-8884-14-4-213.1

Hoham, R. W., Bonome, T. A., Martin, C. W., and Leebens-Mack, J. H. (2002). A combined 18S rDNA and rbcL phylogenetic analysis of Chloromonas and Chlamydomonas (Chlorophyceae, Volvocales) emphasizing snow and other cold-temperature habitats. J. Phycol. 38, 1051-1064. doi: 10.1046/j.1529-8817. 2002.t01-1-01227.x

Hoham, R. W., Frey, F. M., Mohn, W. W., Felio, J. H., Todd, S., Duncan, J. E., et al. (2008). Optimum growth temperatures of three species of green Chloromonas snow algae from Upstate New York and the White Mountains, Arizona. Arctic Antarct. Alp. Res. 40, 355-363.

Hoham, R. W., and Remias, D. (2020). Snow and glacial algae: a review. J. Phycol. 56, 264-282. doi: 10.1111/jpy.12952

Hothorn, T., Bretz, F., and Westfall, P. (2008). Simultaneous inference in general parametric models. Biometrical J. 50, 346-363. doi: 10.1002/bimj.2008 10425

Huovinen, P., Ramírez, J., and Gómez, I. (2018). Remote sensing of albedoreducing snow algae and impurities in the Maritime Antarctica. ISPRS J. Photogramm. Remote Sens. 146, 507-517. doi: 10.1016/j.isprsjprs.2018. 10.015 
Jukes, T. H., and Cantor, C. R. (1969). "Evolution of protein molecules," in Mammalian Protein Metabolism, ed. H. N. Munro (Amsterdam: Elsevier), $21-132$.

Jung, W., Campbell, R. L., Gwak, Y., Kim, J. I., Davies, P. L., and Jin, E. (2016a). New cysteine-rich ice-binding protein secreted from Antarctic microalga, Chloromonas sp. PLoS One 11:e0154056. doi: 10.1371/journal.pone.0154056

Jung, W., Kim, E. J., Lim, S., Sim, H., Han, S. J., Kim, S., et al. (2016b). Cellular growth and fatty acid content of Arctic chlamydomonadalean. Algae 31, 61-71. doi: 10.4490/algae.2016.31.2.8

Keller, A., Schleicher, T., Schultz, J., Müller, T., Dandekar, T., and Wolf, M. (2009). 5.8S-28S rRNA interaction and HMM-based ITS2 annotation. Gene 430, 50-57. doi: $10.1016 /$ j.gene.2008.10.012

Kim, S., Kim, M. J., Jung, M. G., Lee, S., Baek, Y.-S., Kang, S.-H., et al. (2013). De novo transcriptome analysis of an Arctic microalga, Chlamydomonas sp. Genes Genomics 35, 215-223. doi: 10.1007/s13258-013-0085-5

Koetschan, C., Förster, F., Keller, A., Schleicher, T., Ruderisch, B., Schwarz, R., et al. (2010). The ITS2 Database III-sequences and structures for phylogeny. Nucleic Acids Res. 38, D275-D279. doi: 10.1093/nar/gkp966

Koetschan, C., Hackl, T., Müller, T., Wolf, M., Förster, F., and Schultz, J. (2012). ITS2 database IV: interactive taxon sampling for internal transcribed spacer 2 based phylogenies. Mol. Phylogenet. Evol. 63, 585-588. doi: 10.1016/j.ympev. 2012.01.026

Kol, E. (1968). "Kryobiologie. Biologie und limnologie des schnees und eises. I. Kryovegetation," in Die Binnengewiisser, Vol. 24, eds A. Thienemann, J. Elster, and W. Ohle (Stuttgart: Schweizerbart'sche Verlagsbuchhandlung), 216.

Kol, E. (1971). Green snow and ice from the Antarctica. Ann. Hist. Nat. Mus. Natl. Hung. 63, 51-56.

Kol, E., and Flint, E. A. (1968). Algae in green ice from the Balleny Islands, Antarctica. New Zeal. J. Bot. 6, 249-261. doi: 10.1080/0028825X.1968.10428810

Komárek, J., and Nedbalová, L. (2007). "Green cryosestic algae," in Algae and Cyanobacteria in Extreme Environments. Cellular Origin, Life in Extreme Habitats and Astrobiology, Vol. 11, ed. J. Seckbach (Dordrecht: Springer), 321-342. doi: 10.1007/978-1-4020-6112-7_17

Komárek, O., and Komárek, J. (1999). Diversity of freshwater and terrestrial habitats and their oxyphototroph microflora in the Arctowski Station region, South Shetland Islands. Polish Polar Res. 20, 259-282.

Komárek, O., and Komárek, J. (2001). Contribution to the taxonomy and ecology of green cryosestic algae in the summer season 1995-96 at King George Island, S. Shetland Islands. Nov. Hedwigia 123, 121-140.

Krug, L., Erlacher, A., Markut, K., Berg, G., and Cernava, T. (2020). The microbiome of alpine snow algae shows a specific inter-kingdom connectivity and algae-bacteria interactions with supportive capacities. ISME J. 14, 21972210.

Kumar, S., Stecher, G., Li, M., Knyaz, C., and Tamura, K. (2018). MEGA X: molecular evolutionary genetics analysis across computing platforms. Mol. Biol. Evol. 35, 1547-1549. doi: 10.1093/molbev/msy096

Lemoine, Y., and Schoefs, B. (2010). Secondary ketocarotenoid astaxanthin biosynthesis in algae: a multifunctional response to stress. Photosynth. Res. 106, 155-177. doi: 10.1007/s11120-010-9583-3

Lenth, R. (2019). emmeans: Estimated Marginal Means, Aka Least-Squares Means. $R$ Package Version 1.4.3.01.

Leya, T. (2013). "Snow algae: adaptation strategies to survive on snow and ice," in Polyextremophiles. Cellular Origin, Life in Extreme Habitats and Astrobiology, eds J. Seckbach, A. Oren, and H. Stan-Lotter (Dordrecht: Springer), 401-423. doi: 10.1007/978-94-007-6488-0_17

Ling, H. U. (1996). 10. Snow algae of the Windmill Islands region, Antarctica. Hydrobiologia 336, 99-106. doi: 10.1007/BF00010823

Ling, H. U., and Seppelt, R. D. (1998). Snow algae of the Windmill Islands, continental Antarctica 3. Chloromonas polyptera (Volvocales, Chlorophyta). Polar Biol. 20, 320-324. doi: 10.1007/s003000050309

Liu, C., Wang, X., Wang, X., and Sun, C. (2016). Acclimation of Antarctic Chlamydomonas to the sea-ice environment: a transcriptomic analysis. Extremophiles 20, 437-450. doi: 10.1007/s00792-016-0834-x

Liu, C., Zhao, X., and Wang, X. (2018). Identification and characterization of the psychrophilicbacterium CidnaK gene in the Antarctic Chlamydomoas sp. ICE-L under freezing conditions. J. Appl. Phycol. 30, 3519-3528. doi: 10.1007/s10811018-1492-4
Liu, S., Zhang, P., Cong, B., Liu, C., Lin, X., Shen, J., et al. (2010). Molecular cloning and expression analysis of a cytosolic Hsp70 gene from Antarctic ice algae Chlamydomonas sp. ICE-L. Extremophiles 14, 329-337. doi: 10.1007/s00792010-0313-8

Lüdecke, D., Makowski, D., Waggoner, P., and Patil, I. (2020). performance: Assessment of Regression Models Performance. R Package Version 0.4.6.

Luo, W., Ding, H., Li, H., Ji, Z., Huang, K., Zhao, W., et al. (2020). Molecular diversity of the microbial community in coloured snow from the Fildes Peninsula (King George Island, Maritime Antarctica). Polar Biol. 43, 13911405. doi: 10.1007/s00300-020-02716-0

Lutz, S., Anesio, A. M., Edwards, A., and Benning, L. G. (2015). Microbial diversity on Icelandic glaciers and ice caps. Front. Microbiol. 6:307. doi: 10.3389/fmicb. 2015.00307

Lutz, S., Anesio, A. M., Jorge Villar, S. E., and Benning, L. G. (2014). Variations of algal communities cause darkening of a Greenland glacier. FEMS Microbiol. Ecol. 89, 402-414. doi: 10.1111/1574-6941.12351

Lutz, S., Prochazkova, L., Benning, L. G., Nedbalova, L., and Remias, D. (2019). Evaluating amplicon high-throughput sequencing data of microalgae living in melting snow: improvements and limitations. Fottea 19, 115-131. doi: 10.5507/ fot. 2019.003

Lyon, B. R., and Mock, T. (2014). Polar microalgae: new approaches towards understanding adaptations to an extreme and changing environment. Biology (Basel) 3, 56-80. doi: 10.3390/biology3010056

Malavasi, V., Škaloud, P., Rindi, F., Tempesta, S., Paoletti, M., and Pasqualetti, M. (2016). DNA-based taxonomy in ecologically versatile microalgae: a reevaluation of the species concept within the coccoid green algal genus Coccomyxa (Trebouxiophyceae, Chlorophyta). PLoS One 11:e0151137. doi: 10. 1371/journal.pone.0151137

Marchant, H. J. (1982). Snow algae from the Australian snowy mountains. Phycologia 21, 178-184. doi: 10.2216/10031-8884-21-2-178.1

Matsuzaki, R., Hara, Y., and Nozaki, H. (2012). A taxonomic revision of Chloromonas reticulata (Volvocales, Chlorophyceae), the type species of the genus Chloromonas, based on multigene phylogeny and comparative light and electron microscopy. Phycologia 51, 74-85. doi: 10.2216/11-18.1

Matsuzaki, R., Kawai-Toyooka, H., Hara, Y., and Nozaki, H. (2015). Revisiting the taxonomic significance of aplanozygote morphologies of two cosmopolitan snow species of the genus Chloromonas (Volvocales, Chlorophyceae). Phycologia 54, 491-502. doi: 10.2216/15-33.1

Matsuzaki, R., Nozaki, H., and Kawachi, M. (2018). Taxonomic revision of Chloromonas nivalis (Volvocales, Chlorophyceae) strains, with the new description of two snow-inhabiting Chloromonas species. PLoS One 13:e0193603. doi: 10.1371/journal.pone.0193603

Matsuzaki, R., Nozaki, H., Takeuchi, N., Hara, Y., and Kawachi, M. (2019). Taxonomic re-examination of "Chloromonas nivalis (Volvocales, Chlorophyceae) zygotes" from Japan and description of C. muramotoi sp. nov. PLoS One 14:e0210986. doi: 10.1371/journal.pone.02 10986

Matsuzaki, R., Yoshiaki, H., and Hisayoshi, N. (2014). A taxonomic study of snow Chloromonas species (Volvocales, Chlorophyceae) based on light and electron microscopy and molecular analysis of cultured material. Phycologia 53 , 293-304. doi: 10.2216/14-3.1

Maxwell, K., and Johnson, G. N. (2000). Chlorophyll fluorescence-a practical guide. J. Exp. Bot. 51, 659-668. doi: 10.1093/jexbot/51.345.659

Mikhailyuk, T. I., Sluiman, H. J., Massalski, A., Mudimu, O., Demchenko, E. M., Kondratyuk, S. Y., et al. (2008). New streptophyte green algae from terrestrial habitats and an assessment of the genus Interfilum (Klebsormidiophyceae, Streptophyta). J. Phycol. 44, 1586-1603. doi: 10.1111/j.1529-8817.2008.00606.x

Mizuno, Y., Sato, A., Watanabe, K., Hirata, A., Takeshita, T., Ota, S., et al. (2013). Sequential accumulation of starch and lipid induced by sulfur deficiency in Chlorella and Parachlorella species. Bioresour. Technol. 129, 150-155. doi: 10. 1016/j.biortech.2012.11.030

Mock, T., Krell, A., Glockner, G., Kolukisaoglu, U., and Valentin, K. (2006). Analysis of expressed sequence TAGS (ESTS) from the polar diatom Fragilariopsis cylindrus. J. Phycol. 42, 78-85. doi: 10.1111/j.1529-8817.2006. 00164.x

Morel-Laurens, N. M. L., and Feinleib, M. E. (1983). Photomovement in an "eyeless" mutant of Chlamydomonas. Photochem. Photobiol. 37, 189-194. doi: 10.1111/j.1751-1097.1983.tb04457.x 
Müller, T., Bleiß, W., Martin, C.-D., Rogaschewski, S., and Fuhr, G. (1998). Snow algae from northwest Svalbard: their identification, distribution, pigment and nutrient content. Polar Biol. 20, 14-32. doi: 10.1007/s0030000 50272

Müller, T., Philippi, N., Dandekar, T., Schultz, J., and Wolf, M. (2007). Distinguishing species. RNA 13, 1469-1472. doi: 10.1261/rna.617107

Muramoto, K., Nakada, T., Shitara, T., Hara, Y., and Nozaki, H. (2010). Reexamination of the snow algal species Chloromonas miwae (Fukushima) Muramoto et al., comb. nov. (Volvocales, Chlorophyceae) from Japan, based on molecular phylogeny and cultured material. Eur. J. Phycol. 45, 27-37. doi: $10.1080 / 09670260903272607$

Nakada, T., Misawa, K., and Nozaki, H. (2008). Molecular systematics of Volvocales (Chlorophyceae, Chlorophyta) based on exhaustive 18S rRNA phylogenetic analyses. Mol. Phylogenet. Evol. 48, 281-291. doi: 10.1016/j.ympev. 2008.03.016

Nakada, T., and Nozaki, H. (2007). Two species of Chlamydomonas (Volvocales, Chlorophyceae) new to Japan. J. Japanese Bot. 82, 179-189.

Nakada, T., and Nozaki, H. (2009). Taxonomic study of two new genera of fusiform green flagellates, Tabris gen. nov. and Hamakko gen. nov. (Volvocales, Chlorophyceae). J. Phycol. 45, 482-492. doi: 10.1111/j.1529-8817.2009.0 0652.x

Nakayama, T., Watanabe, S., Mitsui, K., Uchida, H., and Inouye, I. (1996). The phylogenetic relationship between the Chlamydomonadales and Chlorococcales inferred from 18SrDNA sequence data. Phycol. Res. 44, 47-55. doi: 10.1111/j.1440-1835.1996.tb00037.x

Oude Vrielink, A. S., Aloi, A., Olijve, L. L. C., and Voets, I. K. (2016). Interaction of ice binding proteins with ice, water and ions. Biointerphases 11:018906. doi: $10.1116 / 1.4939462$

Pawłowska, J., Walther, G., Wilk, M., de Hoog, S., and Wrzosek, M. (2013). The use of compensatory base change analysis of ITS2 as a tool in the phylogeny of Mucorales, illustrated by the Mucor circinelloides complex. Org. Divers. Evol. 13, 497-502. doi: 10.1007/s13127-013-0139-1

Pollio, A., Cennamo, P., Ciniglia, C., De Stefano, M., Pinto, G., and Huss, V. A. R. (2005). Chlamydomonas pitschmannii Ettl, a little known species from thermoacidic environments. Protist 156, 287-302. doi: 10.1016/j.protis.2005.04. 004

Poong, S.-W., Lee, K.-K., Lim, P.-E., Pai, T.-W., Wong, C.-Y., Phang, S.-M., et al. (2018). RNA-Seq-mediated transcriptomic analysis of heat stress response in a polar Chlorella sp. (Trebouxiophyceae, Chlorophyta). J. Appl. Phycol. 30, 3103-3119. doi: 10.1007/s10811-018-1455-9

Procházková, L., Leya, T., Křižková, H., and Nedbalová, L. (2019a). Sanguina nivaloides and Sanguina aurantia gen. et spp. nov.(Chlorophyta): the taxonomy, phylogeny, biogeography and ecology of two newly recognised algae causing red and orange snow. FEMS Microbiol. Ecol. 95:fiz064. doi: 10.1093/ femsec/fiz064

Procházková, L., Remias, D., Řezanka, T., and Nedbalová, L. (2018). Chloromonas nivalis subsp. tatrae, subsp. nov. (Chlamydomonadales, Chlorophyta): reexamination of a snow alga from the High Tatra Mountains (Slovakia). Fottea 18, 1-18. doi: 10.5507/fot.2017.010.Chloromonas

Procházková, L., Remias, D., Řezanka, T., and Nedbalová, L. (2019b). Ecophysiology of Chloromonas hindakii sp. nov. (chlorophyceae), causing orange snow blooms at different light conditions. Microorganisms 7, 1-22. doi: 10.3390/microorganisms7100434

Pröschold, T., and Leliaert, F. (2007). "Systematics of the green algae: conflict of classic and modern approaches," in Unravelling the Algae: The Past, Present, and Future of Algal Systematics, eds J. Brodie and J. Lewis (Boca Raton, FL: CRC Press), 123-153. doi: 10.1201/978084937 9901

Pröschold, T., Marin, B., Schlösser, U. G., and Melkonian, M. (2001). Molecular phylogeny and taxonomic revision of Chlamydomonas (Chlorophyta). I. Emendation of Chlamydomonas Ehrenberg and Chloromonas Gobi, and description of Oogamochlamys gen. nov. and Lobochlamys gen. nov. Protist 152, 265-300. doi: 10.1078/1434-4610-00068

R Core Team (2018). R: A Language and Environment for Statistical Computing, Version 3.5.2. Vienna: R Foundation for Statistical Computing.

Rambaut, A., and Drummond, A. J. (2018). FigTree v1. 4.4. Institute of Evolutionary Biology. Edinburgh: University of Edinburgh.
Raymond, J. A., Janech, M. G., and Fritsen, C. H. (2009). Novel ice-binding proteins from a psychrophilic Antarctic alga (Chlamydomonadaceae, Chlorophyceae). J. Phycol. 45, 130-136. doi: 10.1111/j.1529-8817.2008.00623.x

Raymond, J. A., and Kim, H. J. (2012). Possible role of horizontal gene transfer in the colonization of sea ice by algae. PLoS One 7:e35968. doi: 10.1371/journal. pone. 0035968

Remias, D., Karsten, U., Lütz, C., and Leya, T. (2010). Physiological and morphological processes in the Alpine snow alga Chloromonas nivalis (Chlorophyceae) during cyst formation. Protoplasma 243, 73-86. doi: 10.1007/ s00709-010-0123-y

Remias, D., Procházková, L., Holzinger, A., and Nedbalová, L. (2018). Ecology, cytology and phylogeny of the snow alga Scotiella cryophila K-1 (Chlamydomonadales, Chlorophyta) from the Austrian Alps. Phycologia 57, 581-592. doi: 10.2216/18-45.1

Remias, D., Schwaiger, S., Aigner, S., Leya, T., Stuppner, H., and Lütz, C. (2012). Characterization of an UV- and VIS-absorbing, purpurogallin-derived secondary pigment new to algae and highly abundant in Mesotaenium berggrenii (Zygnematophyceae, Chlorophyta), an extremophyte living on glaciers. FEMS Microbiol. Ecol. 79, 638-648. doi: 10.1111/j.1574-6941.2011. 01245.x

Remias, D., Wastian, H., Lütz, C., and Leya, T. (2013). Insights into the biology and phylogeny of Chloromonas polyptera (Chlorophyta), an alga causing orange snow in Maritime Antarctica. Antarct. Sci. 25, 648-656. doi: 10.1017/ S0954102013000060

Ronquist, F., Teslenko, M., van der Mark, P., Ayres, D. L., Darling, A., Höhna, S., et al. (2012). MrBayes 3.2: efficient Bayesian phylogenetic inference and model choice across a large model space. Syst. Biol. 61, 539-542. doi: 10.1093/sysbio/ sys029

Saitou, N., and Nei, M. (1987). The neighbour-joining method: a new method for reconstructing phylogenetic trees. Mol. Biol. Evol. 4, 406-425. doi: 10.1093/ oxfordjournals.molbev.a040454

Schmieder, R., and Edwards, R. (2011). Quality control and preprocessing of metagenomic datasets. Bioinformatics 27, 863-864. doi: 10.1093/bioinformati cs/btr026

Schultz, J., Müller, T., Achtziger, M., Seibel, P. N., Dandekar, T., and Wolf, M. (2006). The internal transcribed spacer 2 database-a web server for (not only) low level phylogenetic analyses. Nucleic Acids Res. 34, W704-W707. doi: 10. 1093/nar/gkl129

Segawa, T., Matsuzaki, R., Takeuchi, N., Akiyoshi, A., Navarro, F., Sugiyama, S., et al. (2018). Bipolar dispersal of red-snow algae. Nat. Commun. 9:3094. doi: 10.1038/s41467-018-05521-w

Seibel, P. N., Müller, T., Dandekar, T., Schultz, J., and Wolf, M. (2006). 4SALE A tool for synchronous RNA sequence and secondary structure alignment and editing. BMC Bioinformatics 7:498. doi: 10.1186/1471-2105-7-498

Seibel, P. N., Müller, T., Dandekar, T., and Wolf, M. (2008). Synchronous visual analysis and editing of RNA sequence and secondary structure alignments using 4SALE. BMC Res. Notes 1:91. doi: 10.1186/1756-0500-1-91

Selig, C., Wolf, M., Müller, T., Dandekar, T., and Schultz, J. (2008). The ITS2 Database II: homology modelling RNA structure for molecular systematics. Nucleic Acids Res. 36, D377-D380. doi: 10.1093/nar/gkm827

Simoes, C. L., Rosa, K. K., Czapela, F. F., Vieira, R., and Simoes, J. C. (2015). Collins glacier retreat process and regional climatic variations, King George Island, Antarctica. Geogr. Rev. 105, 462-471. doi: 10.1111/j.1931-0846.2015.12091.x

Škaloud, P., and Rindi, F. (2013). Ecological differentiation of cryptic species within an asexual protist morphospecies: a case study of filamentous green alga Klebsormidium (Streptophyta). J. Eukaryot. Microbiol. 60, 350-362. doi: 10.1111/jeu.12040

Soto, D. F., Fuentes, R., Huovinen, P., and Gómez, I. (2020). Microbial composition and photosynthesis in Antarctic snow algae communities: integrating metabarcoding and pulse amplitude modulation fluorometry. Algal Res. 45:101738. doi: 10.1016/j.algal.2019.101738

Stibal, M., and Elster, J. (2005). Growth and morphology variation as a response to changing environmental factors in two Arctic species of Raphidonema (Trebouxiophyceae) from snow and soil. Polar Biol. 28, 558-567. doi: 10.1007/ s00300-004-0709-y

Suzuki, N., and Mittler, R. (2006). Reactive oxygen species and temperature stresses: a delicate balance between signaling and destruction. Physiol. Plant. 126, 45-51. doi: 10.1111/j.0031-9317.2005.00582.x 
Tan, W.-J., Yang, Y.-C., Zhou, Y., Huang, L.-P., Xu, L., Chen, Q.-F., et al. (2018). DIACYLGLYCEROL ACYLTRANSFERASE and DIACYLGLYCEROL KINASE modulate triacylglycerol and phosphatidic acid production in the plant response to freezing stress. Plant Physiol. 177, 1303-1318. doi: 10.1104/pp.18. 00402

Tian, J., and Yu, J. (2009). Changes in ultrastructure and responses of antioxidant systems of algae (Dunaliella salina) during acclimation to enhanced ultravioletB radiation. J. Photochem. Photobiol. B Biol. 97, 152-160. doi: 10.1016/j. jphotobiol.2009.09.003

Trifinopoulos, J., Nguyen, L., von Haeseler, A., and Minh, B. Q. (2016). W-IQTREE: a fast online phylogenetic tool for maximum likelihood analysis. Nucleic Acids Res. 44, W232-W235. doi: 10.1093/nar/gkw256

UniProt Consortium (2019). UniProt: a worldwide hub of protein knowledge. Nucleic Acids Res. 47, D506-D515. doi: 10.1093/nar/gky1049

van Wijk, K. J., and Kessler, F. (2017). Plastoglobuli: plastid microcompartments with integrated functions in metabolism, plastid developmental transitions, and environmental adaptation. Annu. Rev. Plant Biol. 68, 253-289. doi: 10.1146/ annurev-arplant-043015-111737

Vaughan, D. G., Marshall, G. J., Connolley, W. M., Parkinson, C., Mulvaney, R., Hodgson, D. A., et al. (2003). Recent rapid regional climate warming on the Antarctic Peninsula. Clim. Change 60, 243-274.

Vilgalys, R., and Hester, M. (1990). Rapid genetic identification and mapping of enzymatically amplified ribosomal DNA from several Cryptococcus species. J. Bacteriol. 172, 4238-4246. doi: 10.1128/JB.172.8.4238-4246.1990

White, T. J., Bruns, T., Lee, S. J. W. T., and Taylor, J. (1990). Amplification and direct sequencing of fungal ribosomal RNA genes for phylogenetics. PCR Protoc. 18, 315-322. doi: 10.1016/b978-0-12-372180-8.50042-1
Williams, W. E., Gorton, H. L., and Vogelmann, T. C. (2003). Surface gasexchange processes of snow algae. Proc. Natl. Acad. Sci. U.S.A. 100, $562-566$.

Wolf, M., Chen, S., Song, J., Ankenbrand, M., and Müller, T. (2013). Compensatory base changes in ITS2 secondary structures correlate with the biological species concept despite intragenomic variability in ITS2 sequences-a proof of concept. PLoS One 8:e66726. doi: 10.1371/journal.pone.0066726

Yallop, M. L., Anesio, A. M., Perkins, R. G., Cook, J., Telling, J., Fagan, D., et al. (2012). Photophysiology and albedo-changing potential of the ice algal community on the surface of the Greenland ice sheet. ISME J. 6, 2302-2313. doi: 10.1038/ismej.2012.107

Zienkiewicz, K., Du, Z.-Y., Ma, W., Vollheyde, K., and Benning, C. (2016). Stress-induced neutral lipid biosynthesis in microalgae - Molecular, cellular and physiological insights. Biochim. Biophys. Acta Mol. Cell Biol. Lipids 1861, 1269-1281. doi: 10.1016/j.bbalip.2016.02.008

Conflict of Interest: The authors declare that the research was conducted in the absence of any commercial or financial relationships that could be construed as a potential conflict of interest.

Copyright (c) 2021 Gálvez, Saldarriaga-Córdoba, Huovinen, Silva and Gómez. This is an open-access article distributed under the terms of the Creative Commons Attribution License (CC BY). The use, distribution or reproduction in other forums is permitted, provided the original author(s) and the copyright owner(s) are credited and that the original publication in this journal is cited, in accordance with accepted academic practice. No use, distribution or reproduction is permitted which does not comply with these terms. 